\title{
Phased Construction Completion Report for Bldg. K-1401 of the \\ Remaining Facilities Demolition Project at the \\ East Tennessee Technology Park \\ Oak Ridge, Tennessee
}

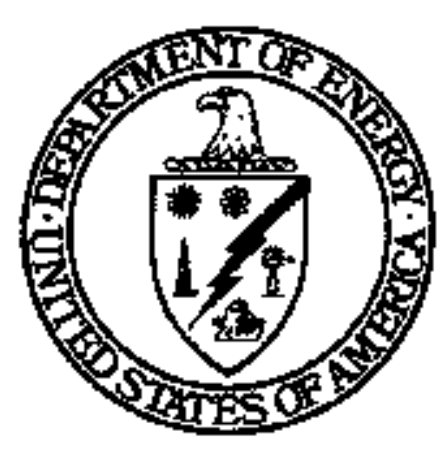

This doctmont is approved tor public releasse per reviow by:

B.B. Marshall

$\frac{9 / 5 / 08}{\text { Dod }}$

BJCETTP Classification \&

Information Control Office 


\title{
Phased Construction Completion Report
} for Bldg. K-1401 of the

\section{Remaining Facilities Demolition Project at the \\ East Tennessee Technology Park \\ Oak Ridge, Tennessee}

Date Issued-October 2008

Prepared for the

U.S. Deparment of Entergy

Office of Environmental Maragement

\author{
BECHTEL JACOBS COMPANY LLC \\ managing the \\ Environmental Maragement Activities at the \\ East Tennessee Technology Park \\ Y-12 National Security Complex Oak Ridge National Laboratory \\ under contract DE-AC05-98OR22700 \\ for the \\ U.S. DEPARTMENT OF ENERGY
}




\section{CONTENTS}

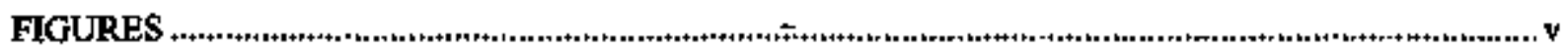

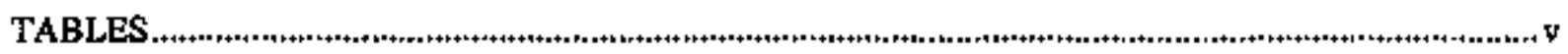

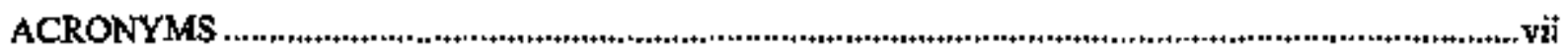

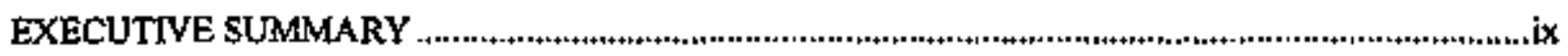

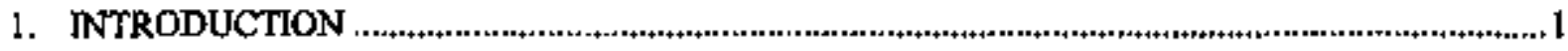

2. SITE AND FACILITY DESCRIPTION

2.1 SITE DESCRIPTION

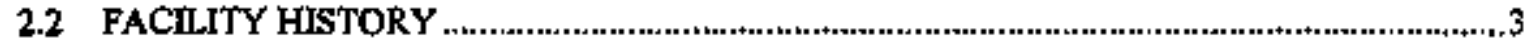

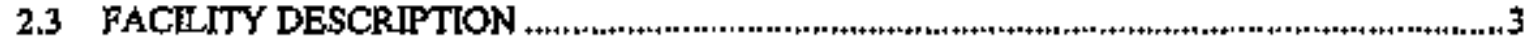

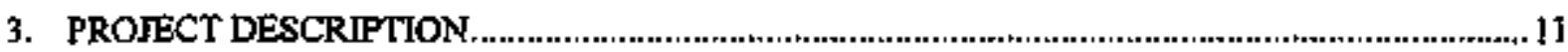

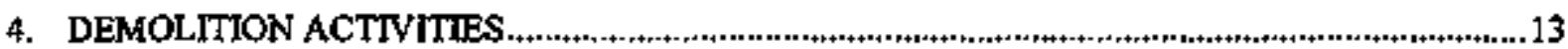

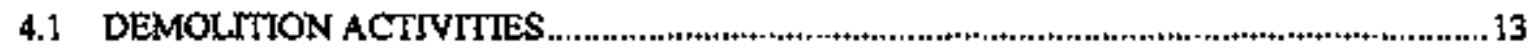

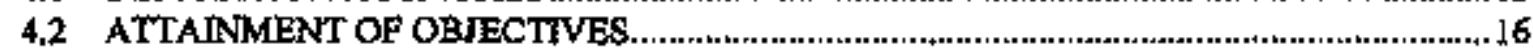

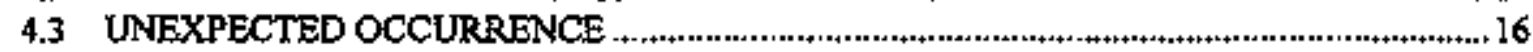

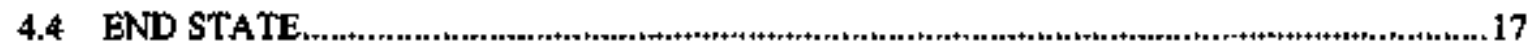

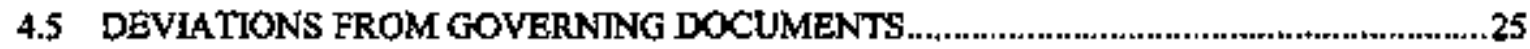

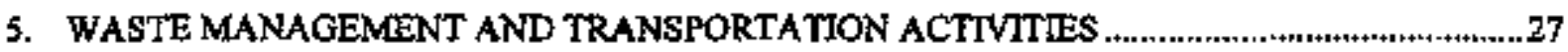

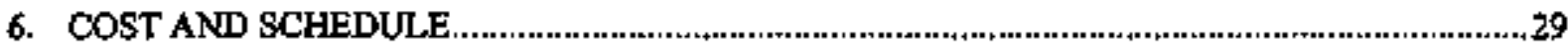

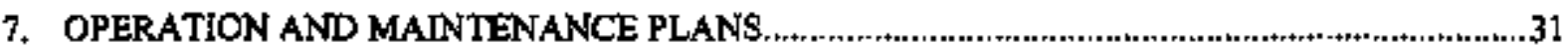

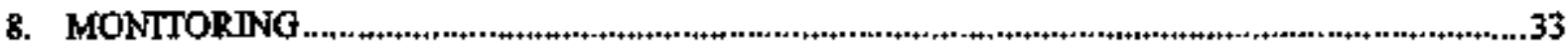

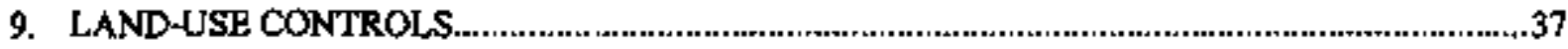

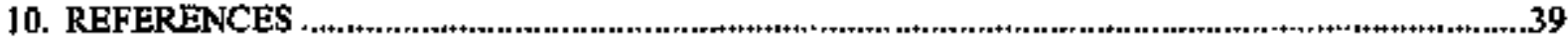




\section{FrgURES}

Fig. 1. Location of B]dg. K-1401, .....................................................................................................4

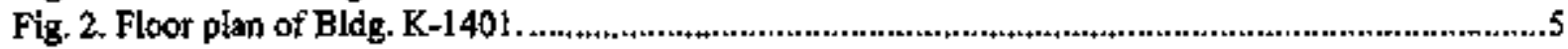

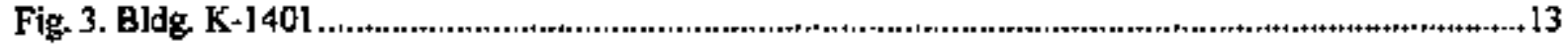

Fig. 4. Bldg. K-1401 during demolition, +..t...................................................................................... 5

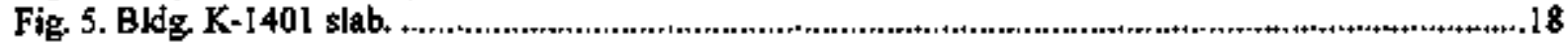

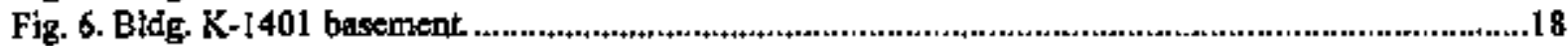

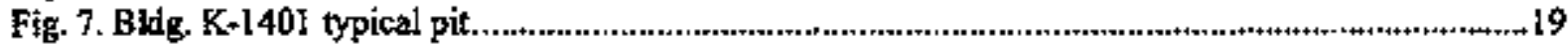

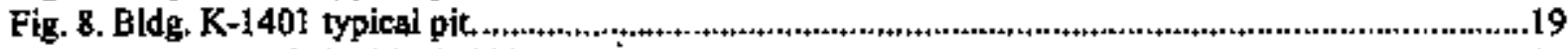

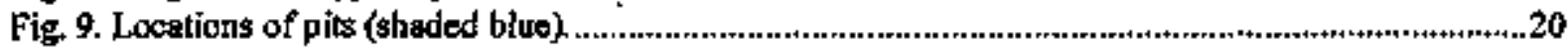

Fig. 10. Radjological sampie results on the slab. ..............................................................................21

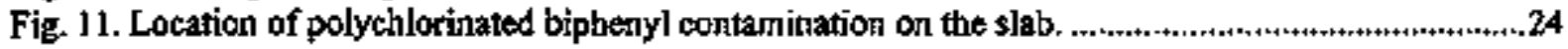

\section{TABLES}

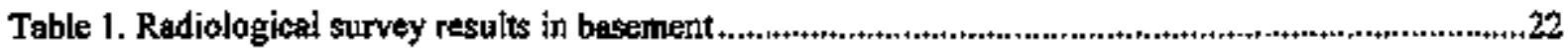

Table 2. Radiological survey results on slab..........................................................................................23

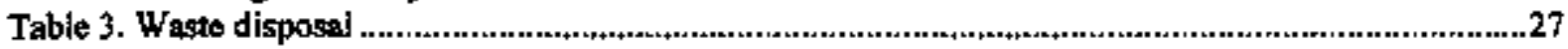

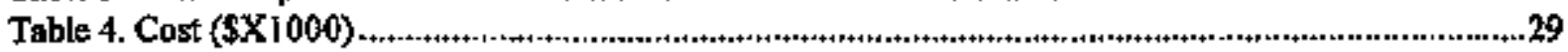

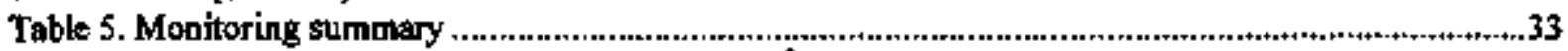

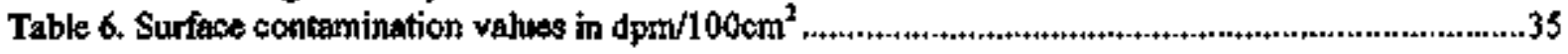




\section{ACRONYMS}

$\begin{array}{ll}\text { BJC } & \text { Bechtel Jacobs Company LLC } \\ \text { CFR } & \text { Code of Federal Rogulations } \\ \text { DOE } & \text { U.S. Department of Energy } \\ \text { EMWMF } & \text { Environmental Management Waste Managentent Facility } \\ \text { ETTP } & \text { East Tennessee Technology Park } \\ \text { WHP } & \text { Waste Handling Plan }\end{array}$




\section{EXECUTTVE SUMMARY}

This Phased Construction Completion Report documents the demoltition of Bldg. K-1401, Maintenance Bujlding, addressed in the Action Momorandum for the Remaining Facilities Demolition Project at East Tennessee Technology Park, Oak Ridge, Ternessee (DOE 2003a) as a Comprehensive Environmental Response, Compensation, and Liability Act of 1980 non-time-ertical removal action. The objectives of the removal action (DOE 2003a) to elininate the source of potential contamination, to eliminate the threat of potential future releases, and/or to eliminate the threats to the general public and the environmentwere met.

The end state of this action is for the stab to remain with all penetrations sealed and grouted or backfilled. The basenent and pits remain open. There is residual radiological and polychiorinated biphenyl contamination on the slat and basement. A fixative was applied to the arta on the pad contaminated with polychloriaated biphenyls. Interim land-use controls will be maintained until final remediation decisions are made under the Zone 2 Record of Decision (DOE 2005a).

Demolition of Bldg. K.1401 was completed for $\$ 26,820,000$. 


\section{INTRODUCTION}

This Phased Construction Completion Report docuritents the demolition of BIdg. K-1401, Maintenance Building, addressed in the Action Memorandym for the Remaining Facilties Demolition Project at East Tennessee Technology Park, Oak Ridge. Tennessee (DOE 2003a) as a Comprehensive Environmental Rısponse, Compensation, and Lisbility Act of 1980 (DOE 2003b) non-time-critical removal action. The purposes of this Phased Construction Completion Report are to:

- Describe the demolition activities completed.

- Document the post-demolition conditions.

The docements that govern this ection are the Engineering Evaluation/Cost Analysis (DOE 2000); Action Mernorandua (DOE 2003a); Standard Operating Protocal (DOE 2003c); Waste Handling Plan (WHP), Part 1 (DOE 2003d); and Waste Handling Plan, Part 2 (DOE 2005b; DOE 2005c).

The scope of this action, as required by the Action Memorandum (DOE 2003a) is to demolish Bldg. K.1401 and dispose of the demolition waste. 
Pusc Intentionally Left Blank 


\section{SITE AND FACILITY DESCRIPTION}

\subsection{SITE DESCRIPTION}

The East Tennessee Technology Park (ETTP), formerly kuown as the Oak Ridge Gaseous Diffision Plant and the K.25 Sitse, begas operations in World War In as part of the Manhattan Project. The original mission was to produce entiched uranium for use in atomic weapons. The plant prodiaced enriched uranium for the commercial nuckear powter industry from 1945 to 1985. Uranium production at ETTP was terminated in 1987. The site is managed by the U.S. Department of Energy (DOE).

The primary contaminarts of concern at ETTP follow:

- Is groundrater-volatile organic compounds (trichloroethene is gerierally the most prevalent compound)

- In sedimentrmeinorganic elements, radionuclides, and polychlorinated biphenyls

- In soils-rinorganic elements, radionuclides, semivolatile organic conpounds, particularly the polycyclic aromatic hydrocarbons, and volatile organic compounds

- In facilities - radionuclides and polychlorinated biphenyls (abandoned facilities also pose a safety hazard to workers.)

\subsection{FACILITY HISTORY}

Bidg. K-1401, Maintenance Buifiding, was constructed in the early 1940s as a maintenance facility supporting the gasecus diffusion process. Pieces of process equipment, such as motors, converters, and compressors, were brought into the facility to be cleaned or repatred. Since most of this equipeneat came from process areas, various amounts and types of radiological contamination were present, thus contaninating the equipment and surfaces of Blog. K-1401. Radiologieal contanination in the building

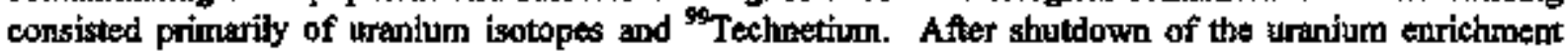
process, Bldg. K-1401 continued to support other aotivities at ETTP. Areas of the building that were not being used to support other activities at ETTP were tutilized for the storage of radiologically contanimated and suspected radiologicaily contaminated exuipment and tuaterial. Subsequently, the majority of the space in Bldg. K-I401 was leased and occupied by private companies under the management of the Communtry Reuse Organization of East Tennesses (BJC 2004). Section 2.3 toentifies the artas that were leased to the Community Rense Organization of Esat Tennesset.

\subsection{FACILITY DESCRIPTION}

Figure 1 sehematically depiets the general location of Bldg. K-1401. A floor pian is in Fig. 2, and a discussion of the main areas of the building follows. 


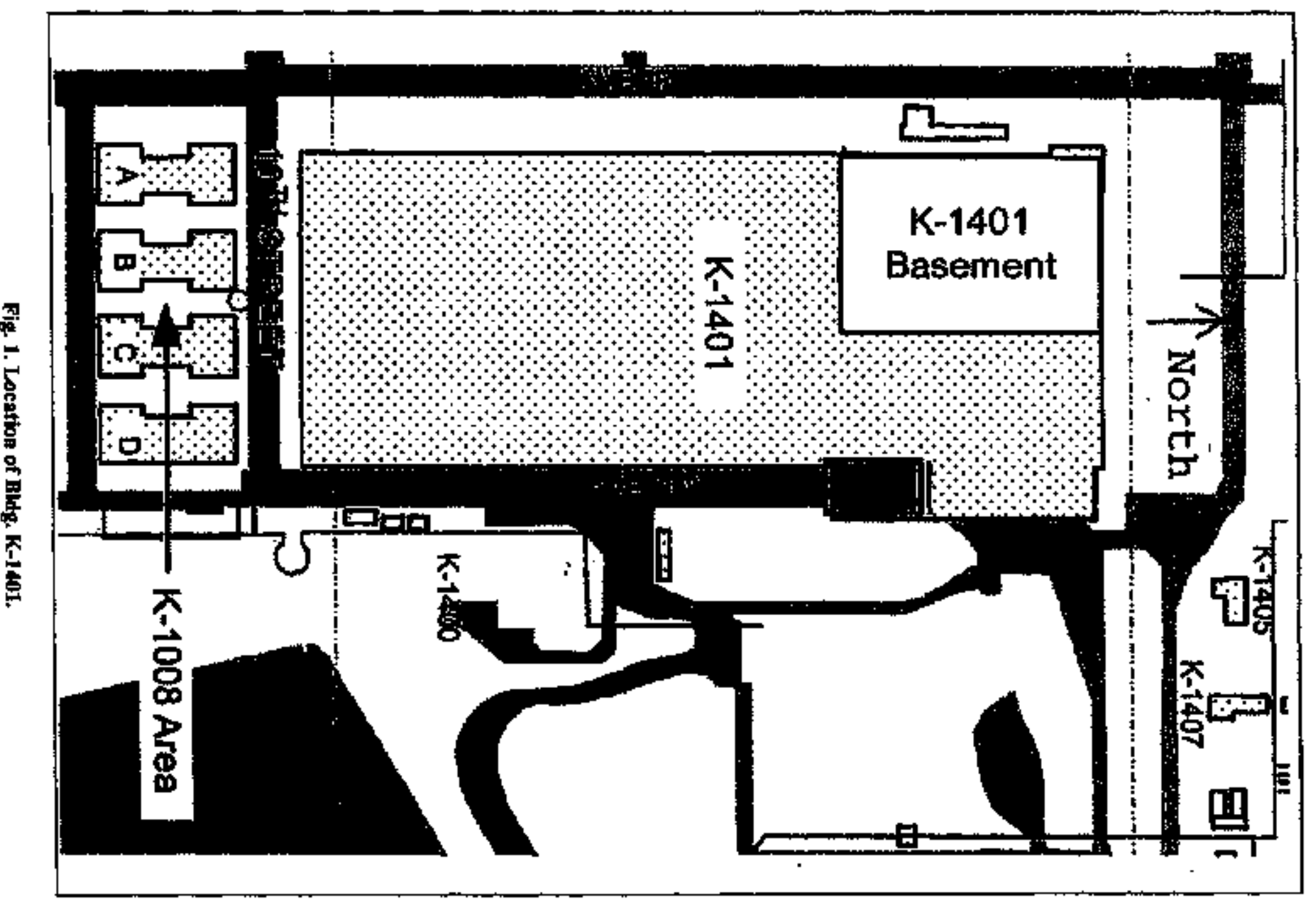




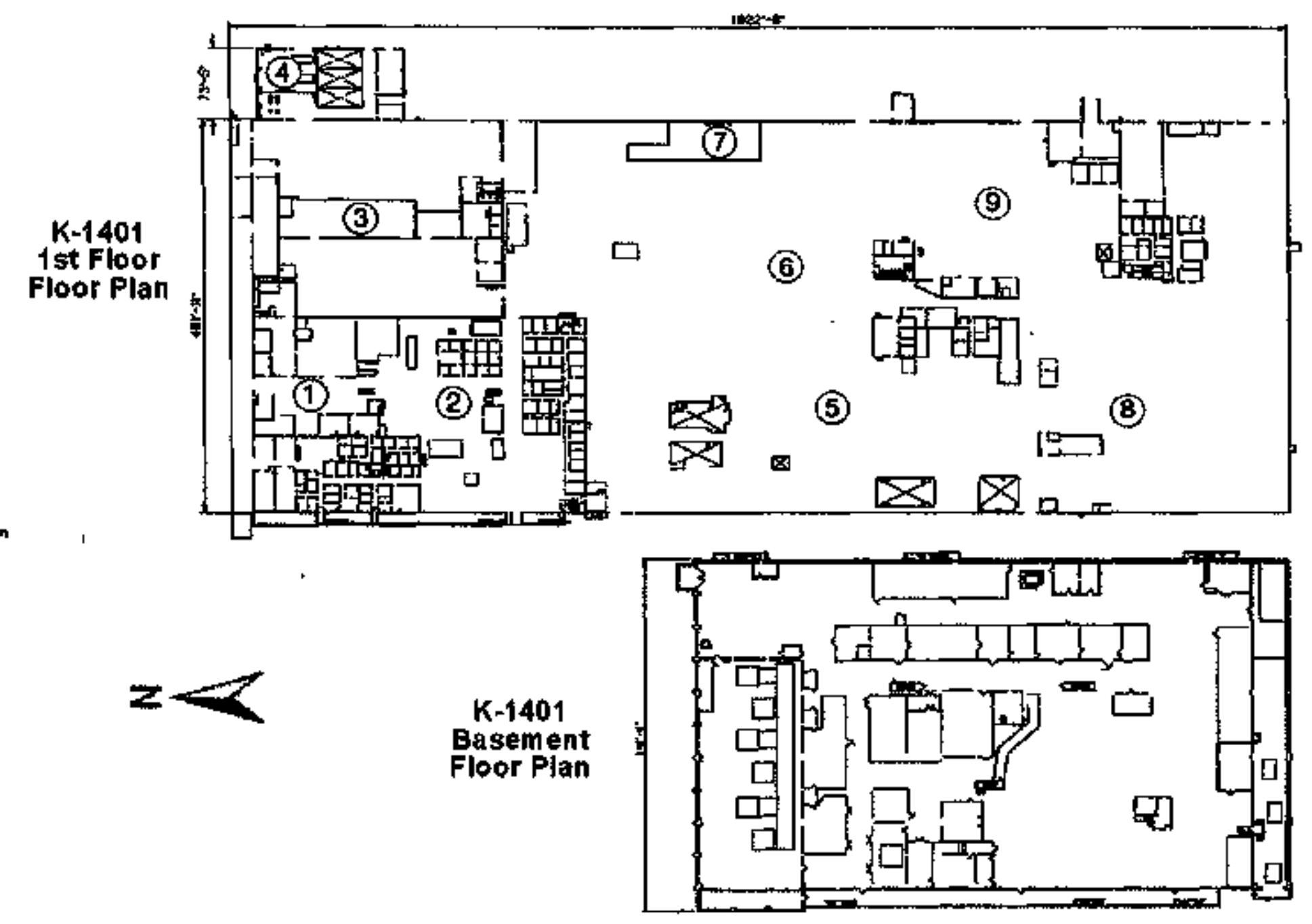

Fig. 2. Foor phan of Bidd. K-140t. 
Bldg. K-1401 was primarily a single-story, high-bay stucture on a concrete slab. Figure 2 presents the floor plan of Bldg. K-140]. The building had a steel trame, and the exterior walls were constructed with brick and conugated asbestos-cement (transite) siding. The roof was tar and gravel (BJC 2004). Bldg. K-140i was rectangular measurting about $400 \mathrm{ft} \times 1000 \mathrm{ft} \times 32 \mathrm{ft}$ tall. There was a basement measuring approximately $200 \mathrm{ft} \times 340 \mathrm{ft}$ in the northwest comer of the building. An addition to the building measurtog approximately $73 \mathrm{ft} . \mathrm{x} 113 \mathrm{ft} . \mathrm{x} 17 \mathrm{ft}$. tall was located on the northeast comer of the building.

A summary of part activities is given below by facility area:

- Area 1. This area contrined offices, laboratories, and test areas. The laboratory ares was used for the development and testing of instrumentation systems ased in the cascades. In the 1940s and 1950s, a 20-stage gaseous diffusion pitot plant was locafed where Roons 255 and $E 4$ were boahed. It was removed in the Jate 1950s. The development and hesting laboratories were mostly abandoned and were used to store abandoned equipment and materiats. Room 255 was a siress-testing laboratory.

- Area 2. In the 1970 s, converters from Bldg. K-27 were treated in the stands with fluorine before being sent to the gaseous diffusion plant in Paducah, Kenticky. Room E4 in the northeast comker of Area 2, which was built in the 1970s, contained the Seal Laboratory and compressor best stands. Four idle furnace stands were located in the southwest seation of the area and were enclosed by drywall struchures.

- Area 3. Area 3 was composed of three large high-bay areas separated by two walls running notth and south. The west two areas were the Jig and Fixture Shops. These rooms contajned dritl presses, lathes, and milting machines Much of the equipment was tydraulic in nature and contained tubricating oils. There was evidence on the floors thet incioental spills occutred, but there is no dooumented evidence to budicatte that there were any large reteases An extensive sumpling program performed in 1991 showed no polychlorineted bypbenyls above regulatory concem in the equipment. Each room had an overhead crape that traversed the length of the room. There were offices in several locations. The Jig and Fixture Shops were leased to the Community Reuse Organization of East Tennessee.

The east portion of Area 3 was used in conjunction with Ares 4 to install, test, and assemble barrier tube bundles in the process converters. This operation lasted from the $1940 \mathrm{~s}$ into the 1980s, and large quantities of fluorine were ased in the process.

A cinder block room was constructed in the northeast corner of Area 3 for the temporary storage of pesticides that were moved from Bldg. K-1407 in 1989. The pesticides were stored in this room for $2 \%$ years until a permanent storago room was constructed.

All equipment was romoved from the east room of Area 3. This room had numerous areas of contamination on the floor, and several attempts were made to remove it, with litale success.

- Area 4. Area 4 contained three large walk-in fumaces used to treat converters, prepared in Area 3. Pror to demolttion, the are to the north of the fumaces in Area 4 had been decontaminated, and the large, metal heat-treaking oven hat been removed Three large tanks located in a room to the south of the fumaces contained potassium hydroxide. The potassium hydroxide tanks associated with the furnaces in Area 4 were in place, but empty.

- Area 5. This area was a large, open lifh bay divided into areas for fabrication and mainterance of various types of equipment. It contrined machine shop-type equipment, such as drill presses, lathes, and milling machines, as well as areas for cleaning, repeiring, and assembling equipment. As equipment became idle in the 19901, the area began to collect abandoned equiprnext and material and was posted as a radiofogical contaraination area. in 1997-98, the equipment and material in this area 
were removef, and the floor and walls (up to $8 \mathrm{ft}$.) of the area were decontaningted. Areas 5 and 6 received most of the attention during the 1998 project to decontaminate portions of the floor space of Bldg. K-1401. The abandoned equipment and materials were removed. Several pits in the area were associated with some of the previons larger equipment. This area was leased to the Community Reuse Orgarization of East Tennessee.

- Area 6. The northern section of this area was the pump shop. It was used to repair and/or rebuild the pumps used in the uranium entichment process. When the gaseous diffusion process was shut down in 1985, the area began to collect abandoned contaminated and potentially contaminated equipment and material. The northern section of Area 6 was posted as a radiofogicaliy contaminated area until 1998. In 1997-98, the equipment and material in this area were removed, and the area was decontarninated as described in Area 5. This section of Area 6 was leased to the Community Reuse Organization of East Tennessee.

In the southwest corner of Atea 6 were a two-story office and bxeak area and the Quality Control Test Facility. The test facility was used for inchustrial radiography by X-ray, hydrostatic testing toad testing of slings, checking pressure relief valves and gas pressure regalators, and volumetric testing and necertification of gas cylinders. The test facility was shut down due to exiensive radiological contamination. In 1993, operations resumed after decontanisation of the aren was completed.

All the equipment and abendoned materbals that were in the northern section of this arrat were removed prior to demolition, and the area was decontrminated. This section was leased to the Community Reuse Organization of East Tennesset.

- Area 7. Area 7 contained the Blakeslee degressers and acid baths that were used, beginning in 1944, for degreasing and cleaning operations for various-sized and -shaped parts associated with the tranturn enrichment process. Actds, alkalis, detergents, and organic vapor degreasers wite used in this process. The cleaning facility was expanded and modified in the early 1970 s to accommodate the cascade improvement and cascade upgrade program. Trichloroethylene was the comunon degreaser from the 1940 s through the 1960 s but was replaced by trichloroethane in the 1970s. The degreasers are metal tanks that sit in pits in the building's fotndation. There was an annular space of 18 inches to 2 feet between the tariks and the foundation. Thre tanks were used to rernove oil and grease contamination fom process pipinge motors, and other equipment. The acid baths were used to remove rust and scale trom process piping and for pickling of nickel and monel piping and parts. Hydrochloric acid and trichloroethane used in the degreasers and baths were stored in tanks actoss Avenue " $D$ " on the east side of the building. The degreasers were olosed usder the technical requirements of Resource Conservation and Recovery Act once operations ceased in 1991.

Residual meretry contamingtion was present in the pits outside the tanks due to the cleaning of material from mercuny tecovery operations in B/dg. K-1420. The only identified releases from this area were through the K-1401 Acid Lines.

Dip tanks were once located in an addition on the northeast comer of the building. These tanks contained trichloroethane, hydrochloric acid, and other solvents used for equipment cleaning and degreasing operations.

- Ares 8. This area was the motor shop, where electric motors from the process buildings were repatred. There wese two walk-in ovens, a spray bookh, and hydraulic ocquipment for refurbishing the motors. The ovens and spray booth had possible intemal radiological contamination. In the 1990s, the area wes converted to the Hoisting and Lifting Mobile Equipment Training Facility. The ovens were renoved in the late 1990s, and the area was leased to the Community Reuse Organization of East Tennessee. There were three offices in the northers portion of this area. 
- Area 9. The nortlern section of Area 9 houged weld shops during the operation of the uranium enrichment process, an oil storage roorn, and the Cordex ${ }^{2 \pi}$ Room.' The southern section contained the sheet metal shop, a carpenter słop, a janitorial storage, a pesticide storage room, a weld shop, and offices. The Cordex Th Room was divided into three rooms and contained dimensional inspection equipment, weld rod storage, and the breathing air compressor. The oil storage room contained 8355 -gallon drums of various oils used for lubricating the equipmemt and machinery throughout the building. There was a fenced area $(20 \times 20 \mathrm{ft}$ ) that contained a covered pit with a piece of equipment that was posted as containing intensl radicactive contamination. The janitorial storage arsa contained numerous cleaning supplies and the pesticide storage roon. A battery-cherging station was also located in this area. The northern half of this area was leased to the Commumity Reuse Organization of East Tennessee.

- Laading dock. On the north of Bkg. K-1401 was a loading dock. The dock had an ovechead gantry crane that spanned the dock and a railraad siding that served the dock.

- Baserwent. There was stairway access to the basement area in the norttiwest corner of the first foor. The basement area of Bldg. K-1401 was located under Areas 1 and 2. It was in use from 1944 to 1987. Process equipnent in this area origimilly supported the converter conditioning stands on the first floor of the building. Fluorine for the test and treament faciltities in Area 2 was piped from BIdg. K-1302 (Fluorine Storage Facility) through the basement. Most of the basement area originally contained process equipment and piping. Some of the process piping was jemoved in calendar year 2000. Canals were below the basement floor slab to distribute ventilation air throughout the basement. Ventilation fans for ench of the five canals continuously blew air over the standing groundwater in the canals and discharged that air into the basement.

The ventilation system for circulating air to the main floor of Bldg. K-1401 was constructed of transite utateriai. This transite ductwork connected to the large ventilation fans through metal ductwork that bad polychiotinated biphenyl gaskets. Numerous pieces of equipment in Bldg. K.1401 had the potential to contair ojls with polycklorirated biphenyl contamination. Freono was located in airconditioning units throughout the basement Chemicals and materials locested to the basement are potentislly radioactively contenninated.

A time-critical removal action (DOE 1997) was conpleted (DOE 1998) to collect contaninated groundwater from the sumps in Buildings $\mathrm{K}-1401$ and $\mathrm{K}-1420$ and to pump the groundwater to the Centeral Nestralization Facility for treatment. The treated wastewater was than discharged to the Clineh River. Prior to this time-critical removal sction, the contaminated groundwater was dischargeo into storm drains that discharged into Mitchell Branch and then into the Clinch River. The pelrpose of the removal axtion was to reduce risk to hutman health and the environment by preventing contaminated groundwater in the sumps from entering nearby surfare waters. A Removal Action Report Addendum (DOE 2006) documents a decision made by the Federal Facility Agreement Project Managers on December 15, 2005 that there is no need to continue to collect water from the sumps in Buildings K-1420 and K.1401 for the purpose of groundwater profection. However, for Building K-1401 there was a requirement to operate the suzap pumps continuously until butlding demolition is complete and then as needed to support any needed remetial action.

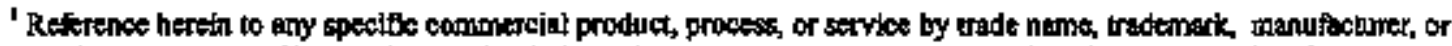

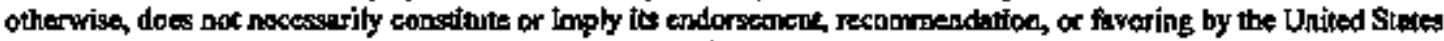
Goverament or any apency therefof or its costrectors or subcentractors.
} 
- Roof. A radiological survey and characterization for hazardous materials on the northern section of the roof of Bldg. K-1401 was conducted in 1996. The core sample that was collected to suppont characterization of hazardous materials was comprised of multiple layers, inciuding a base sheet, two layers of insulation (perlite/cellulose layer and $\bar{a}$ form sheatfing layer), felt, and asphalt/pitch. The radiological survey determined that radioactive material contaminated above DOE Order 5400.5 (DOE 1993) limits was present on the followimg roof components: penthouse, an 8 × 10-ft. roof area, vent pipe cover, air intake unit (louver), and ventilator stack.

- Drain Lines. The Bldg. K-1401 Acid Line runs underground along the cast side of Bldg. K-1401 and was used to transfor corrosive solutions from Bidg. K-]401 to the Bldg. K-1407-A Neutralization Facility. The line was taken out of service in 1987. Waste streams that were transported through this fine include degreaser solvents, caustics, and acids used to clean equipment contarainated with uranizme hexafluoride.

Vent Lines. The vent line originating at Bldg. K-1401 extended from the north side of the building to the railroad tracks. The line was constructed of 3-, 4-, and 6-in. dianeter pipe and was suspended $20-30 \mathrm{ft}$ above the ground. The line was used to transport exhaust gases from Bldg. K-140: to the K-1300 Stack. 
Page Intentionally Left Blank 


\section{PROJECT DESCRIPTION}

The objectives of the overall removal action (DOEE 2003a) are to demolish the facilities in order to eliminate tho:

- Sourter of potential contamination.

- Threat of potential future releases.

- Threats to the general public and the environment

The applicable or relevant and appropriate requirements are contained in the Action Memorandum (DOE 2003a) and Standard Operating Protocol (DOE 2003c).

The scope of the overall removal action, as reçuired by the Action Menoxandun (DOE 2003a), is:

- Characterization of facilities and debris, as required for waste segregation and worker safety.

- Abatement of asbestos and hazarctous materials.

- Removal of equipment

- Prysical demolition of the above-grade structure to the concrete slab (remediation of slaba, basements, and underlying soil is the responsibility of the ETTP Remedial Actions Project consistent with the ETTP Zone 1 [DOE 2002], Zone 2 [DOE 2005a], and future Sitewide Records of Decision).

- Characterization of basements to strpport future Comprehensive Environmental Response, Contpensation, and Lisbility Act decisions prior to backfilling.

- Radiological decontamination of any concrete slab that will be exposed after conpletion of denulition actions. In the unlikely event that satisfactory decontamination cannot be accomplished, cover material or coatings will be applied to accomplish the required level of shielding from radioactive contaminants. A final radjologieal survey will be porformed following the decontarniunation activities to ensure that no additiontal institutional controls will be required.

- Segregation and packaging (including stzing, as nexessary) of demolition debris materials for transportation and disposal.

- Treatment of waste, as necessary, to meet the waste acceptance eriteria of the selected disposal facility. It is anticipated that all sanitary wastes will be disposed in the Oak Ridge Reservation Industrial Laxdfill, and low-lovel and mixed wastes will be disposed in the Environmental Management Waste Management Facility (EMWMF). Wastes that do not jaeet the EMWMF waste acceptance criteria will be disposed off-site.

- Safe fransportation of all wastes generated from demolition activities through to a point of final disposition.

- Final dispostion of all waste generated from demolition activities in accordance with applicable regulatory requirements. 
Page Intentionally Left Blank 


\section{DEMOLITION ACTIVITIES}

Below is a summary of the dernolition activities, the attainment of project objectives, unexpected occurtences, and state, and deviations from governing documents.

\section{4,1 DEMOLITION ACTIVITIES}

Bldg. K-140] (Fig, 3) was demolished as follows:

- Completed pre-WHP (DOE 2005b; DOE 2005c) activities in the basement:

- DOE requested and received approval from the Environmental Protection Agency and Tennessete Department of Environment and Conservation to perform specific work th the basement prior to the approval of the WHP. The basement was a storage area and was classified as a Contamination Arsa with severat High Contamination A ress. Materials that were left in the besement were packaged in appropriate containers to be shipped upon approval of the WHP. Rennaining unpackaged material was relocated in the basement to allow access to clean out the process lines and for asbestos abatement. The process lines were purged and steam cieaned to remove hazirdous rnaterial. Class 1 asbestos removal was conducted to support the process line clean out. The asbestos material was stored in Bldg. K-1401 until approval of the WHP. Equipment in the basement was removed prior to demolition of the basenent.

- The building slab was posted a Contamination Area.

- Anomalous matertat generated from the demolition of Precominately Uncontaminated or LowRisk Low Complexity facilities being stored in B[dg. K-140] was appropriately characterized and disposed before demolition of Bldg. K-1401.

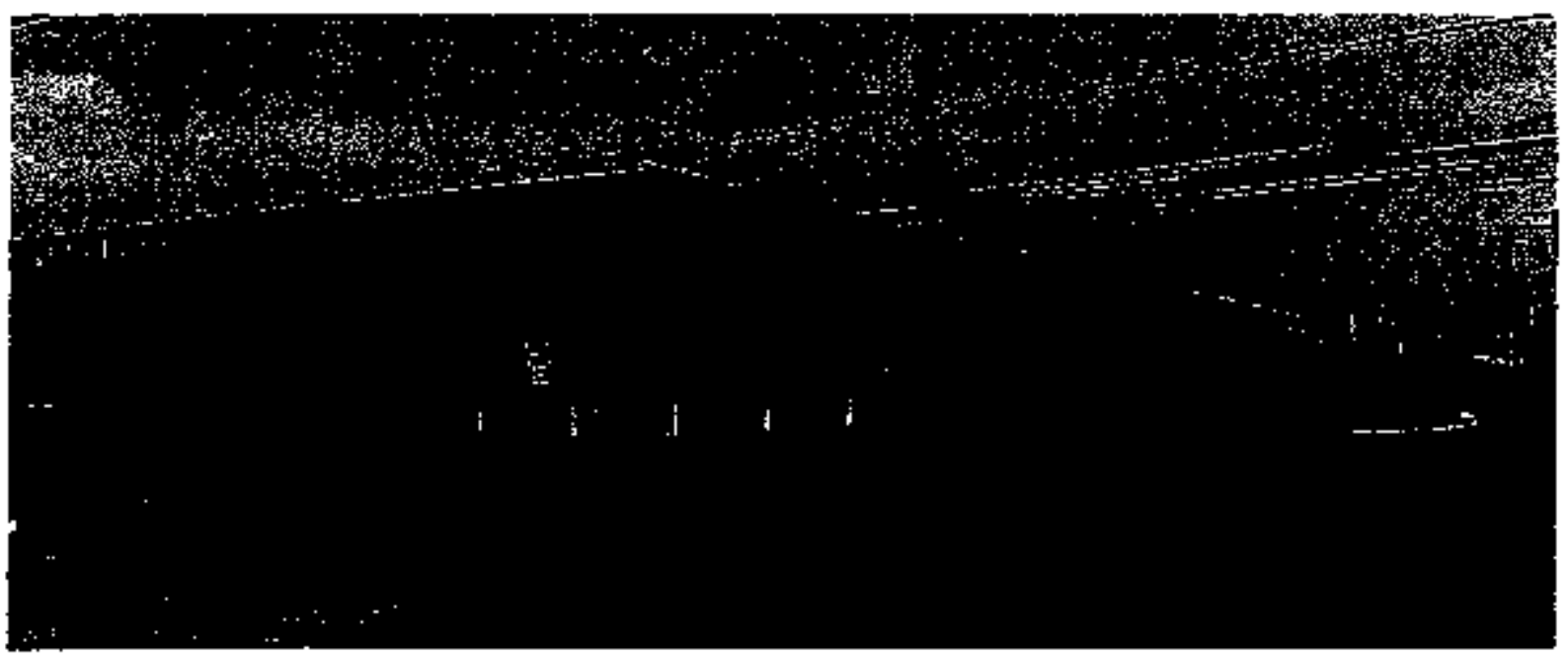

Fìg. 3. Bldg. K-1401. 
- The sump pumps in the bagement were operated until no longer required to support demoltion.

- The utilities connected to BIdg. K-1401 were deactivated.

- Universal waste was radiologicalfy surveyed for refegse from the Contamination Area and disposed at a commercial factitity.

- Liquids and oils were drainedrergoved and disposed as follows:

- Liquid waste [groundwater (see Sect. 2.3)] pumped from the basement during demolition initially was sent for treatment and disposal at the ETTP Central Neutralization Facility. In October 2006 the liquid white was sent for treatment at the K-1401 A trestment facility and subsequent disposal to the santtary sewer. This change was made because of plans to shut-down the ETTP Central Neutralization Facility and was reflected in a Non-Significant Change to the Action Memorandum for Rerouting of Sump Discharge from Buildings K-140I and K-1420 (DOE 2007), Rainwater that collected in the pits was pumped into the basement for disposal along with the other witer in the basement.

- Oils were semt for treatment and disposal at the ETTP Toxic Substances Control Act incinerator.

- Hazardous wastes wero removed for treatunent and disposal by an off-site vendor.

- Selected equipnent and matertals from the first floor and basement were staged and disposed at the EMWMF and Y-12 Landfill.

- Areas of bigh radiological contamination, and with waste regulated by the Resource Conservation and Recovery Act, were staged and disposed at EnergySolutions.

- Equipment and piping in the basement with high "Technetium contamination were size reduced and placed in ST-90 containers for shipment to Energysolutions. Most of this equipment and piping was removed prior to denolition of the building. The rematining items, such as piping circuit boards, lead debris, contaminated demolition debris, and merrury ampoules were acoumulated in a waste mamagement storage area until a surficient quantity was availsbie to justify a shipment

- Asbestos was removed, double-wrapped, and shipped to EMWMF.

- Equipment and piping with high ${ }^{93}$ Technetium contamination that could not be removed prior to demolition was spray painted or otherwise indicated as not beinti eligible for EMWMF disposal. This equipment and piping was disposed at Energy Solutions.

- The remaining building structure and its contents were demolished and disposed at EMWMF (Fig. 4).

- Loose contarnination remaining inside the facility was sprayed with a fixative prior to demolition.

- Equipment, with loose contamination that could not be demolisbed with the facility was removed from the facility, wrapped, and disposed at EMWMF and EnergySolutions.

- The facijity was derzolished and size-reduced with mechericai equipment The floor over the basenent was collapsed into the basement Any debris in the basement from the dernolition of the first floor slab was removed and disposed with the balance of the Bldg. K-140] waste. All debris was loarled into dump trucks and hauled to EMWMF for disposal. 


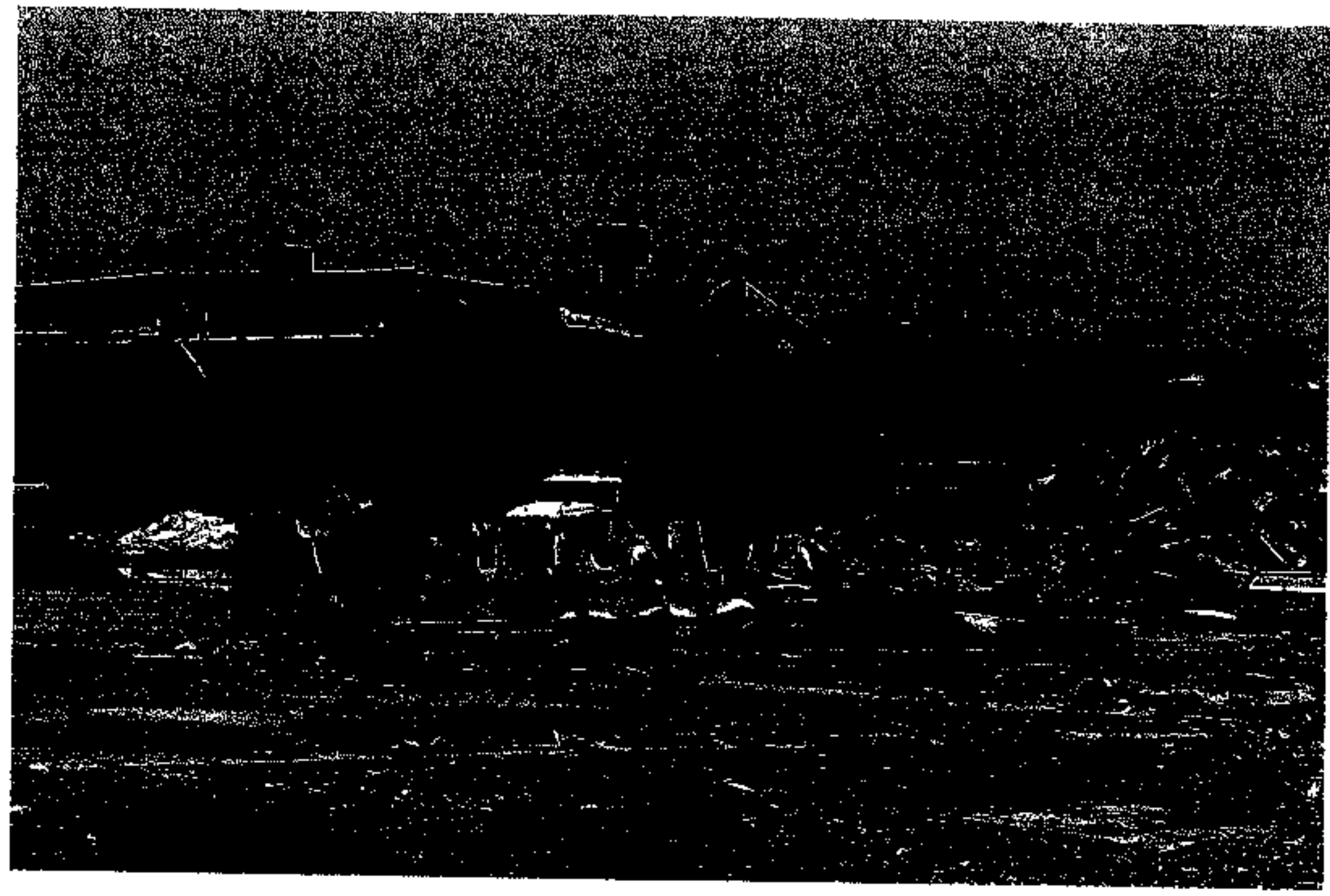

Fig. 4. Bdor. K-1401 during demolitton. 


\subsection{ATTAINMENT OF OBJECTTVES}

The objectives of this action (DOE 2003a) were met as shown below:

- Dernolished facilities reduce the threat of release of hazardous substances from the deteriorating sinuctures, remove potentigl hazards to on-site personnel from contaminated above-slab structures, and reduce the potential hazards of residual contamination from the slab.

- Survey results were dacumented and provided to the ETTP Remedial Action Project for further evaluation for the remaining siab.

- The National Historic Preservation Act, Sect 106, process was followed, resulting in a Memorandurn of Agreenent to demolish the facilities.

- Aquatic resousrces were protected by implementing best management practices of installing hay bales around storm drains and runoff areas to control water flow through the demolition areas.

- Ambient air monitoring was conducted during the demolition process to ensure no release of particulates and radiological contaninants and the protection of workers removing asbestos.

- Radiological perimeter sarveys were performed before and after demolition to ensure contaminant migration did not ocour.

- Amended water solutions were used during the asbestos atbatement process to prevent release of airborme particulates.

- Wastes were properly disposed. During demolition groundwater in the basement was pumped out and sent to the Central Neutralization Facility initially and the K-140]-A treatment facility subsequently for treturneot (sest. Sect. 4).

- The radiological controls in place end inaplemented during demolition indicate that comtannination did not migrate from the control areas at levels that created new of elevated contamination zones surrounding the building.

\subsection{UNEXPECTED OCCURRENCE}

During demolition of Bldg. K-I401, the following unexpested occurrence took place. On the aftemoon of August 7, 2007, the project tsam discovered that a section of process gas vent pipe pre-identified not to be included in EMWMF waste profile for Waste Lot 14.14 (Bldg. K-1401 demolition waste) was not located with other such pre-identified waste. At the time of discovery, the project was downsizing process pipe waste and peckaging it in ST-90 boxes for shipment off-site to a commercial disposal facility. The project tmmediately suspended shipmests of waste to EMWMF and began searching for the section of pipe. This search untovered a 12-ft. section of the pipe. The next moming, the project initiated an investigation to evaluate the loss of control of the waste and intensified the search of all debris ptles at the Bidg. K-1401 site. On August 17, 2007, an additional 20-ft. section of the pipe was found.

The pipe in question was the chlofide tif-fluorine process gas vent pipe that came out of the west basement wall, rars up the west side of the building, and vented to the atmosphere at the top of the building above the roof line. The pipe was approximately $65 \mathrm{ft}$. in length, $4 \mathrm{kn}$. in cianeter, made of copper, and painted green and beige to matcb the exterior of the buikding. This paint scheme made this pipe very diffiealt to recognize, as it blended in with the other stractural building debris. The vent pipe had been identified for 
off-site disposal and was supposed to be painted for easy identification and segregation. The pipe was never painted, so it was not segregated from the rest of the waste to be disposed at the EMWMar.

The two sections ( $12 \mathrm{ft}$ and $20 \mathrm{ft}$ ) of the pipe that were found were segregated and placed in ST-90 boxes for shipment off-site to a commercial disposal fecility. Following the investigation, DOE determined that the remaining $33 \mathrm{ft}$ of pipe were disposed at the EMWMF. The pipe was characterized for disposal under an approved waste profile for Energysolutions using coupon samples from pipe inside the basement. The pipe was not contaminated with Resource Conservation and Recovery Act hazariolus waste or poiychlorinated biphenyl waste. It was contaminated with "Techanetium, with an upper confidence leval $95 \%$ concentrition of $-30,000 \mathrm{pCi} / \mathrm{g}$. The sum of fractions for the pipe was 110 , and the effect on the volumetric sum of fractions for the EMWMF is negitigible (a 10-4 effect). The pipe meets the administrative and physical waste acceptance criteria for the EMWMF and has no impact for future disposal of waste at the EMWMF.

On August 20, 2007, a managstrient assessment of the Bldg. K-1401 demolition project approved the resumption of shipments to EMWMF. Shipments were resumed on Augast 21, 2007.

Three coupon samples from the recovered portion of the vent pipe were collected on October 1,2007 for use in characterizing the portion of that pipe that was disposed in the EMWMF. Results from the analyses performed on the coupon samples contimed that the pipe was copper and was not a hazardous waste. The ${ }^{9}$ Technetiugn results were also very close to the values used to characterize the pipe for Eneroysolutions disposal $(15,300 \mathrm{pCi} / \mathrm{g}, 1 \mathrm{l}, 100 \mathrm{pCV} / \mathrm{g}$, and $21,800 \mathrm{pCi} / \mathrm{g})$. These results yiek a slightly lower sum of fractions (approximstely 102) and confirnt a negligible effect on the volumetric stum of finctions for the EMWMF.

\subsection{END STATE}

The concrete slab (Fig 5), basement (Fig. 6), and pits (Fig. 7, 8, and 9) xemain. Plans are tor the basthent and pits to be backiflled and the slab to be removed by the end of Fiscal Year 2008. The basement, pits, and a sizall portion of the slab are posted as a radjologica Contamination Area. The remaining portion of the slab is posted as a Fixed Contsmination Area (Fig. 10). Some areas were surveyed ond released as clean when the residual radiologkal contamination was below the release litmits of DOE Order 5400.5 (DOE 1993). Table 1 confains a sumblary of the results of the basement radiological survey, and Table 2 contains a summary of the slab survey. The survey results for the pits indicate no remedial action is necessary as part of the Zone 2 Record of Decision (DOE 2005a). The radiologisal surveys in the besement were taken in dry conditions prior to demolition of the building. Water was not an issue thenn because it was pumped out The primary constituents contributing to high total beta values were uranium and ${ }^{96}$ Technetium.

The basement floor and slab were contaminated with polychborinated biphenylg. The concentration in the basement ranged from nor-ietect to 130 pprn which is below the cleanup levels defined in the Zote 2 Record of Decision (DOE 2005a). No fixative was applited to the contaminated location (Fig. li) on the pad because the pad was to be removed. This characterization infomation was provided to the Rernedial Action Program. Interim land-use controls have been implentented (see Sect. 9) until final remediation decistons are made under the Zone 2 Record of Decision (DOE 2005a).

Based on the surveys performed and the remaining postings for the slab, annual radiological surveys will be performed until remediation activities take place. 


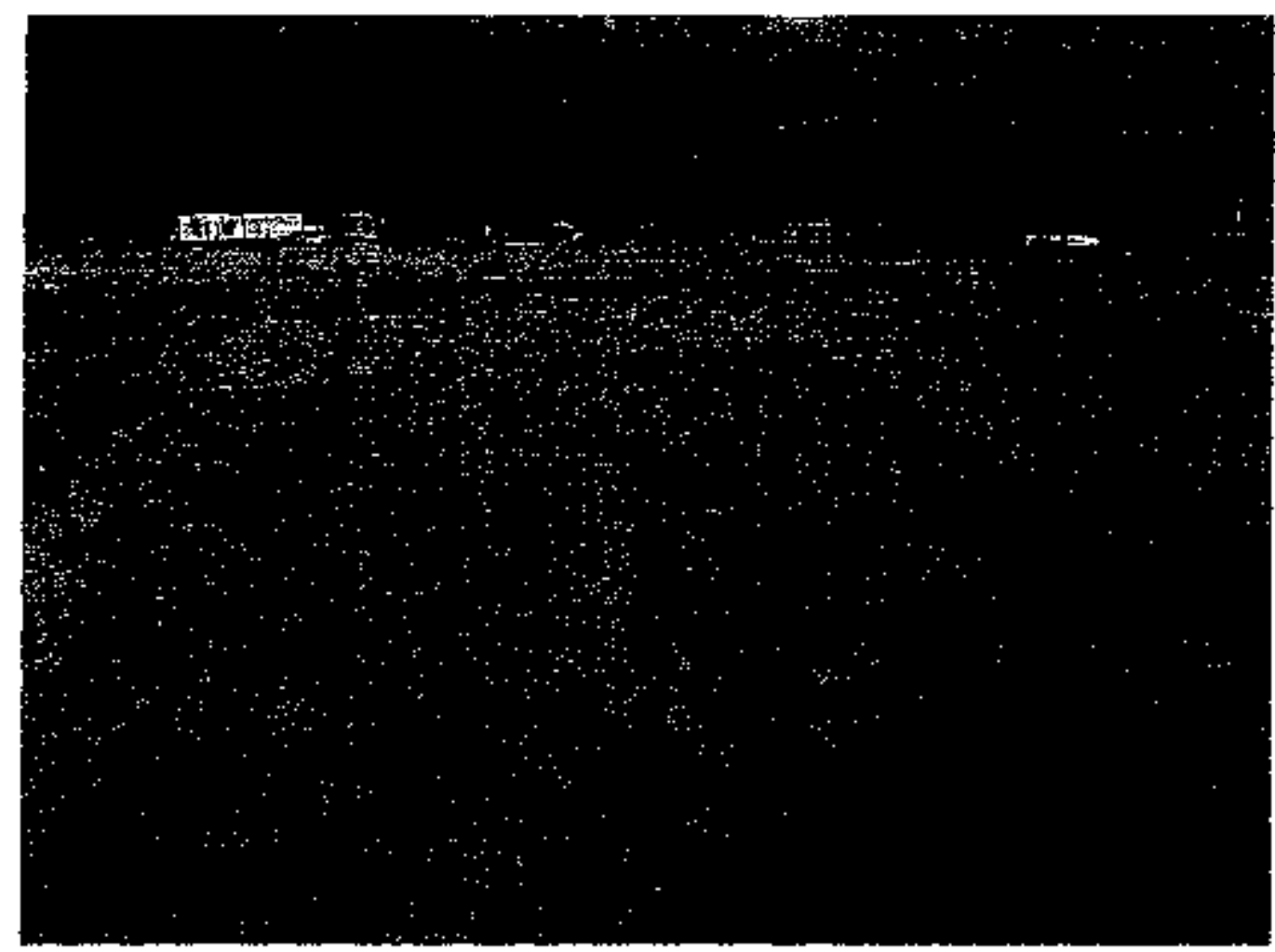

Fig. 5. Blde K-1401 slah.

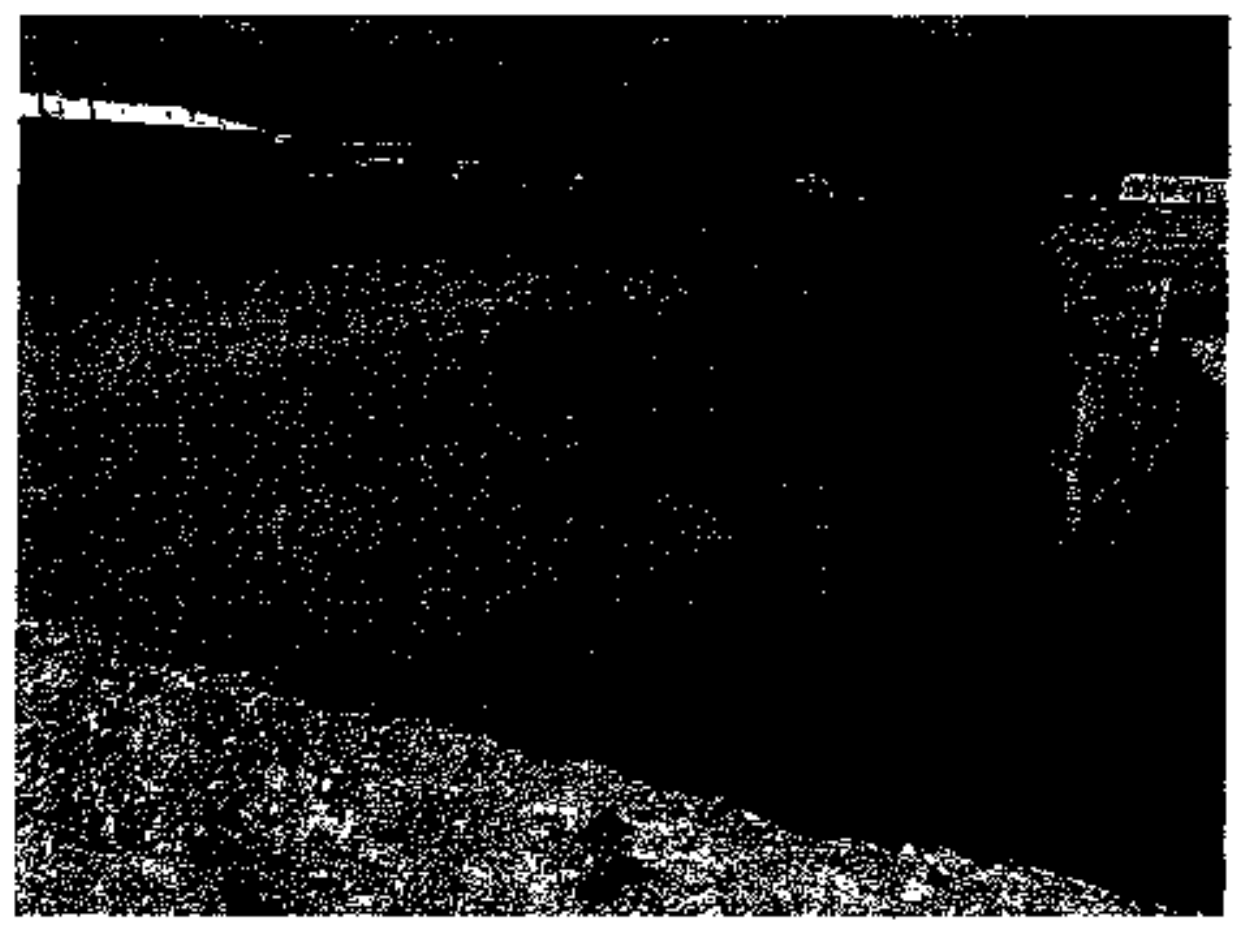

Fig. 6. E1dq K-1401 bacement. 


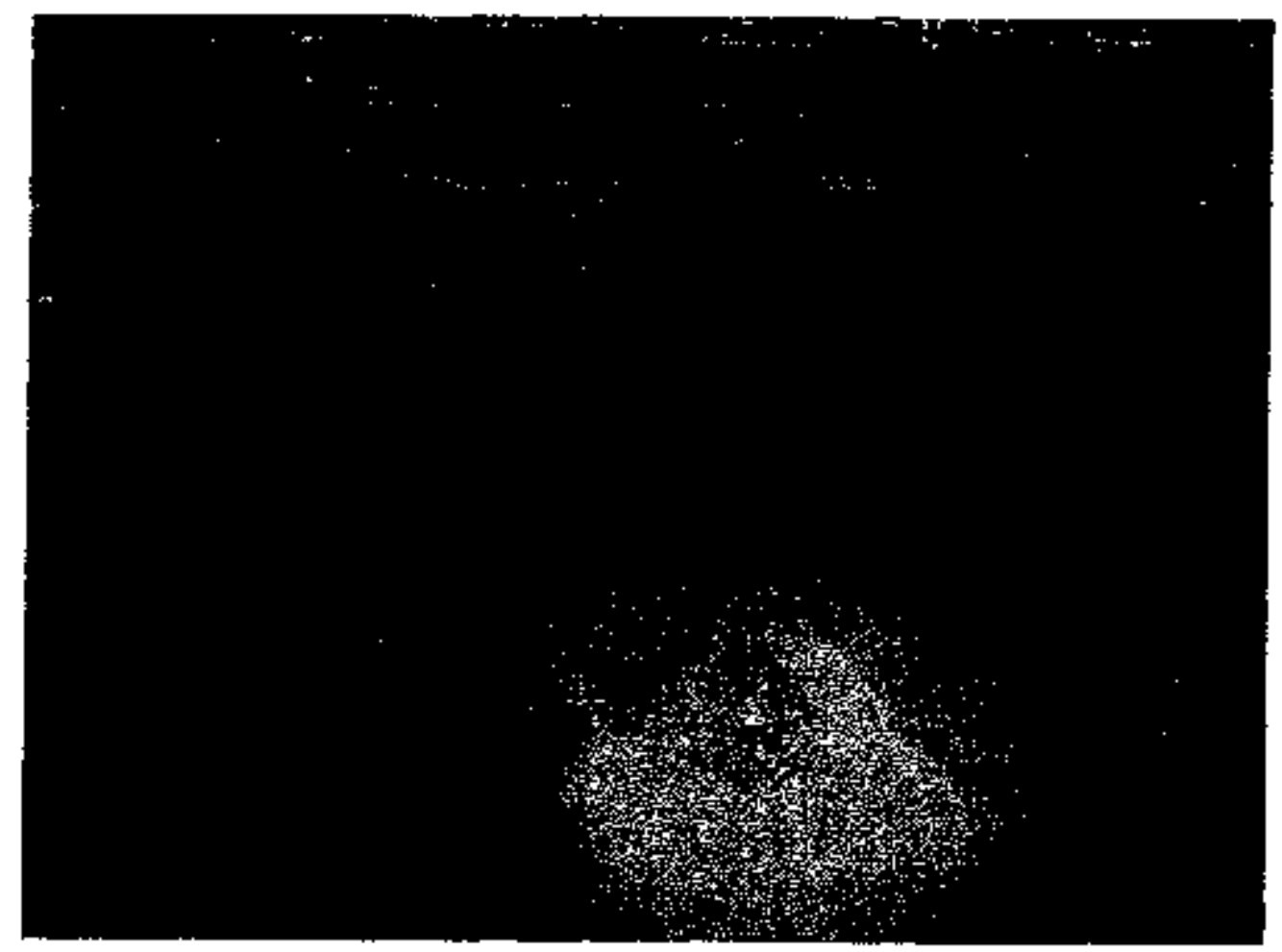

Fte. 7. Bidg K-1401 typical pit

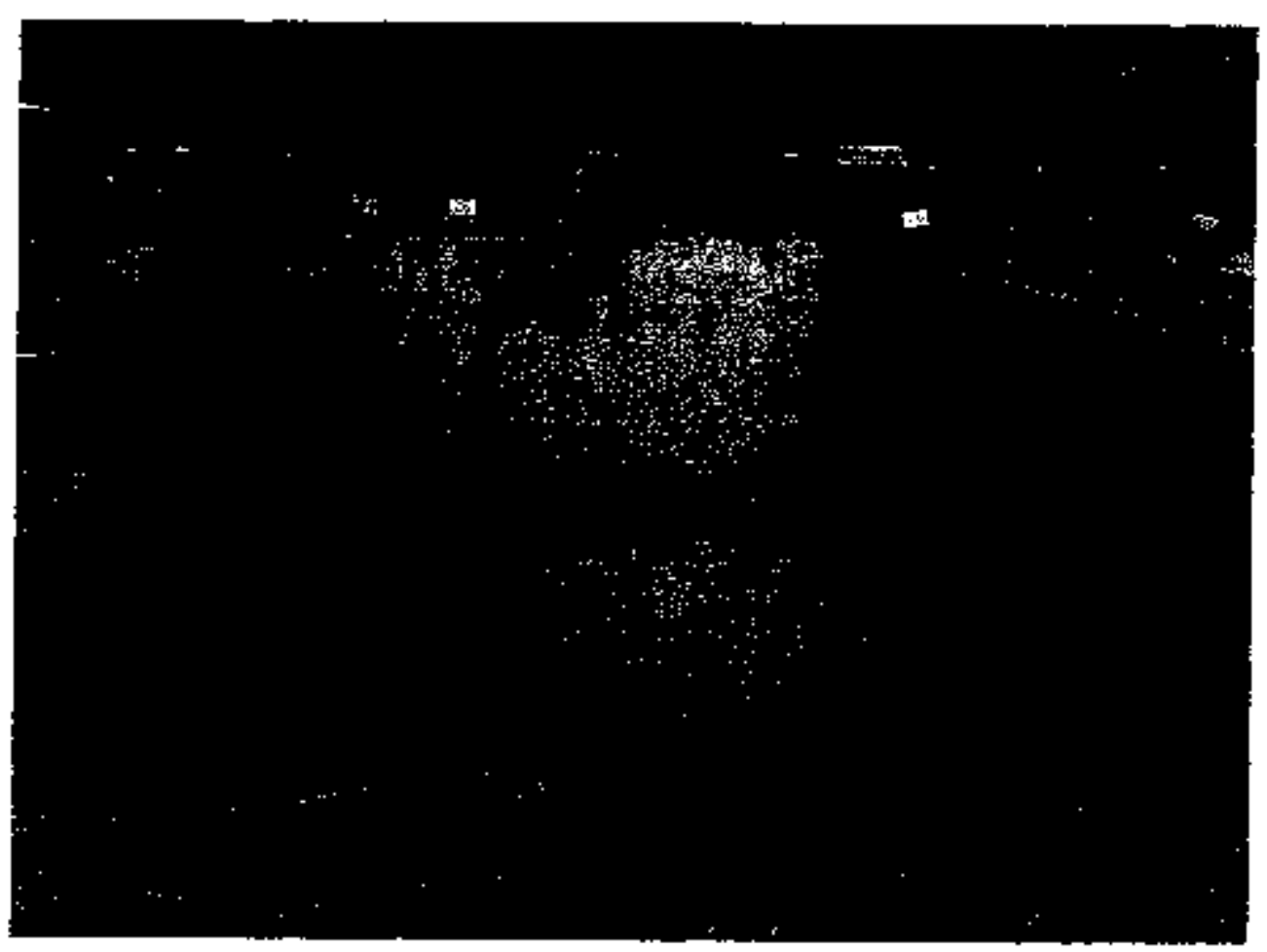

Fig. B. Bddg. K-1401 typical pit. 


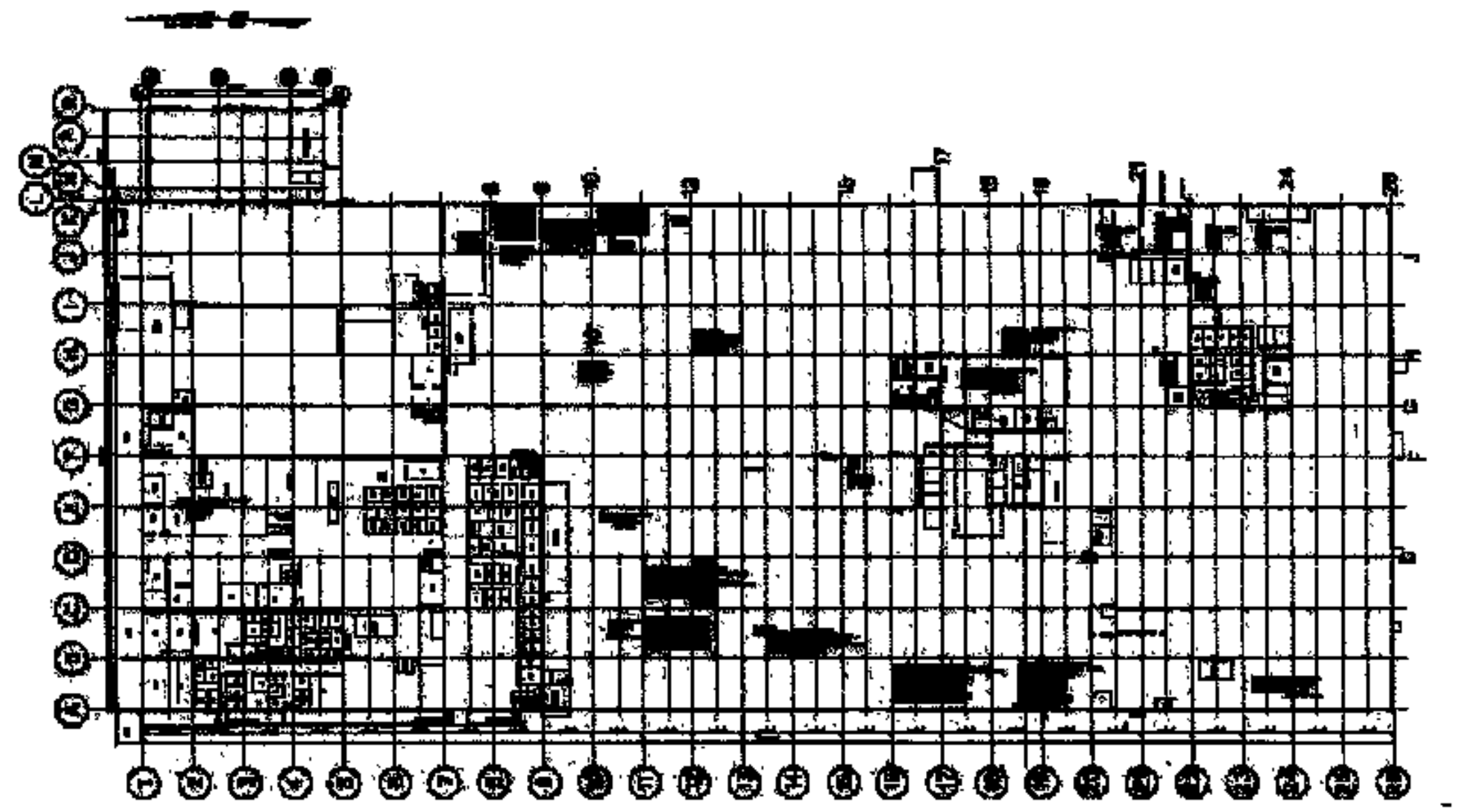

Fig. 9. Locations of ptts (aladed blae). 


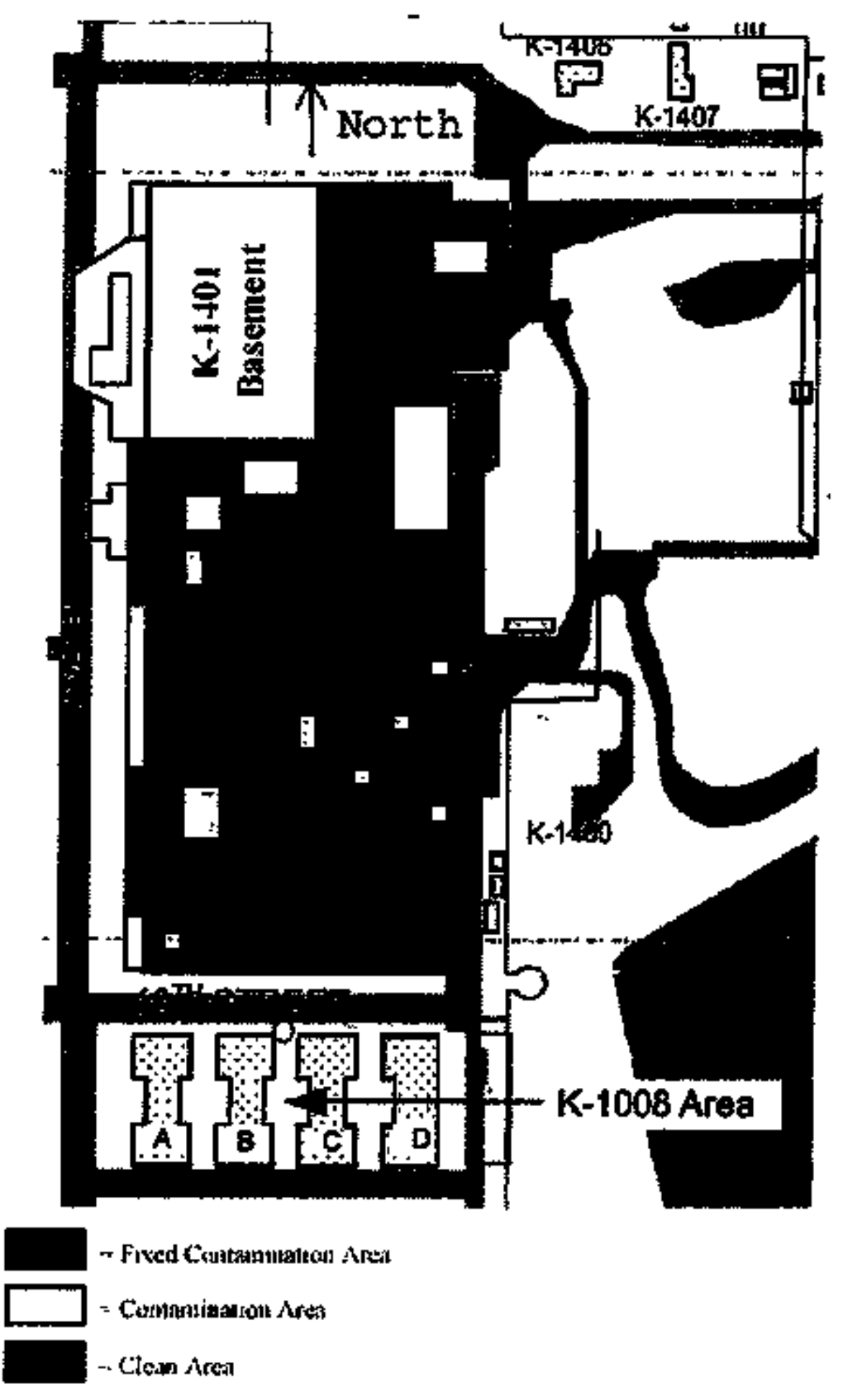

Fie 10. Rodiolngical somple revils on the siab. 
Table 1. Rediological strvey resalts in bostment

\begin{tabular}{|c|c|c|c|c|c|c|}
\hline Date & Survey & Location, & $\begin{array}{c}\text { Alpah smear } \\
\text { Ftequetcy } \\
\text { Jow/high }\end{array}$ & $\begin{array}{l}\text { Bets sinsar } \\
\text { Frequency } \\
\text { lowhigh }\end{array}$ & $\begin{array}{l}\text { Alpoh tots } \\
\text { Frequtercy } \\
\text { low/high }\end{array}$ & $\begin{array}{l}\text { Betl ental } \\
\text { Frequency } \\
\text { lowhigh }\end{array}$ \\
\hline $5 / 7 / 2007$ & 07-ArtaA-0502 & $\begin{array}{l}\text { Baserment, East } \\
\text { Wal, colmor } \\
\text { line F }\end{array}$ & $\begin{array}{l}027 \\
<1_{-k}\end{array}$ & $\begin{array}{l}0,7 \\
<L_{c}\end{array}$ & $\begin{array}{l}5 / 27 \\
33 / 85\end{array}$ & $\begin{array}{c}3 / 27 \\
519 / 2661\end{array}$ \\
\hline 5/302007 & 07-AreaA-0586 & $\begin{array}{l}\text { Besement, south } \\
\text { Wall }\end{array}$ & $\begin{array}{l}012 \\
<L_{8}\end{array}$ & $\frac{2 / 12}{264 / 332}$ & $\begin{array}{l}4 / 12 \\
18 / 43\end{array}$ & $\begin{array}{c}\$ / 12 \\
225 / 1435\end{array}$ \\
\hline $5 / 2 / 2007$ & 07-Arean-0484 & $\begin{array}{l}\text { Basemint, Nonth } \\
\text { Fan room }\end{array}$ & $\begin{array}{c}1 / 74 \\
73 \\
\end{array}$ & $\begin{array}{l}1 / 74 \\
655 \\
\end{array}$ & $\begin{array}{c}30 / 73 \\
24 / 125\end{array}$ & $\begin{array}{c}12 / 73 \\
455 / 5210\end{array}$ \\
\hline $5 / 7 / 2007$ & A7-AreaA-0501 & $\begin{array}{l}\text { Basement, } \\
\text { sutheast cotancr }\end{array}$ & $\begin{array}{l}\alpha 12 \\
<\mathrm{L}_{0} \\
\end{array}$ & $\begin{array}{l}1 / 12 \\
277\end{array}$ & $\begin{array}{r}3 / 12 \\
27 / 63 \\
\end{array}$ & $\begin{array}{c}12 / 2 \\
277 / 164 \\
\end{array}$ \\
\hline $5 / 9 / 200 n$ & 07-AreaA-05il & $\begin{array}{l}\text { Baseinent, wect } \\
\text { wall }\end{array}$ & $\begin{array}{l}3 / 24 \\
27 \% 6\end{array}$ & $\begin{array}{c}6 / 24 \\
619 / 6633\end{array}$ & $\begin{array}{l}5 / 24 \\
46 / 211\end{array}$ & $\begin{array}{c}1024 \\
1094 / 94353\end{array}$ \\
\hline $5 / 9 / 2007$ & 07 -Aread-0512 & $\begin{array}{l}\text { Bescinent, } \\
\text { northwest correr }\end{array}$ & $\begin{array}{l}3 / 26 \\
18225\end{array}$ & $\begin{array}{c}3 / 26 \\
450 / 21490\end{array}$ & $\begin{array}{c}10 / 26 \\
\text { IB/554 }\end{array}$ & $\begin{array}{c}26 / 26 \\
380 / 70470\end{array}$ \\
\hline Shon2007 & on-Areat-0525 & $\begin{array}{l}\text { Batsentent, } \\
\text { northwest end }\end{array}$ & $\begin{array}{l}0 / 16 \\
<I_{n}\end{array}$ & $\begin{array}{l}0 / 16 \\
<1_{*}\end{array}$ & $\begin{array}{l}916 \\
1982\end{array}$ & $\begin{array}{c}15 / 16 \\
275 / 35305\end{array}$ \\
\hline 5/1J2007 & 07-AstaAd0573 & 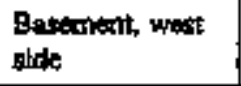 & $\begin{array}{l}14 / 40 \\
17 / 10 \mathrm{~A}\end{array}$ & $\begin{array}{c}19 / 40 \\
667 / 11481\end{array}$ & $\begin{array}{c}32 / 40 \\
17 / 2292\end{array}$ & $\begin{array}{c}4040 \\
896268177\end{array}$ \\
\hline $5 / 1 \leq / 2007$ & 07-AreaA-0533 & $\begin{array}{l}\text { Basement, } \\
\text { cuter area }\end{array}$ & $\begin{array}{l}61 / 62 \\
9 / 613\end{array}$ & $\begin{array}{c}37 / 62 \\
862 / 44812\end{array}$ & $\begin{array}{l}61 / 62 \\
8 / 5671\end{array}$ & $\frac{62162}{1486 / 5729340}$ \\
\hline $5: 6 \sqrt{2007}$ & $07-A r t a A-0562$ & $\begin{array}{l}\text { Bryenient, } \\
\text { soxthcast tind }\end{array}$ & $\begin{array}{c}4 / 50 \\
17 / 300 \\
\end{array}$ & $\begin{array}{c}7 / 50 \\
597 / 3138 \\
\end{array}$ & $\begin{array}{c}21 / 50 \\
1+740 \\
\end{array}$ & $\begin{array}{c}37 / 50 \\
628 / 197874 \\
\end{array}$ \\
\hline $5 / 17 / 2007$ & OR-Area-0539 & $\begin{array}{l}\text { Bescentent, asst } \\
\text { area }\end{array}$ & $\begin{array}{l}8 / 55 \\
1244 \\
\end{array}$ & $\begin{array}{l}0 / 35 \\
<4 \\
\end{array}$ & $\begin{array}{l}25 / 35 \\
5 / 323\end{array}$ & $\begin{array}{c}28 / 35 \\
270 / 57412\end{array}$ \\
\hline $5 / 8 / 2007$ & 07-AreaA-05\$0 & $\begin{array}{l}\text { Busemenh, } \\
\text { conter ares. }\end{array}$ & $\begin{array}{c}6 / 34 \\
14243 \\
\end{array}$ & $\begin{array}{c}3 / 34 \\
36613824\end{array}$ & $\begin{array}{c}16 / 34 \\
15 / 605 \\
\end{array}$ & $\begin{array}{c}34 / 34 \\
305 / 340 / 2\end{array}$ \\
\hline $5 / 232007$ & 07-AveaA-0568 & $\begin{array}{l}\text { Basteminent; } \\
\text { soutburest area }\end{array}$ & $\begin{array}{c}9 / 24 \\
26 / 288\end{array}$ & $\begin{array}{c}22 / 24 \\
262 / 2409\end{array}$ & $\begin{array}{c}22 / 24 \\
37 / 1333\end{array}$ & $\begin{array}{c}24 / 24 \\
635 \sqrt{32921}\end{array}$ \\
\hline 3302007 & 07-ArenA-0S80 & $\begin{array}{l}\text { Basement HCA } \\
\text { Heas }\end{array}$ & $\begin{array}{c}32 / 33 \\
15 / 2877\end{array}$ & $\begin{array}{c}33 / 93 \\
670 / 19856\end{array}$ & $\begin{array}{c}33 / 33 \\
8 / 1739\end{array}$ & $\begin{array}{c}33 / 33 \\
7660 / 1895890\end{array}$ \\
\hline
\end{tabular}

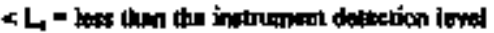

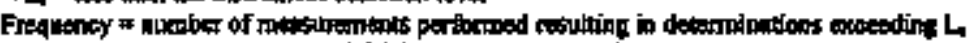

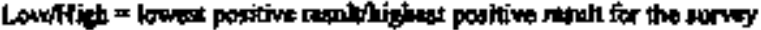

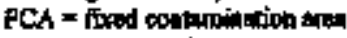

$C A=$ ocotandindion area

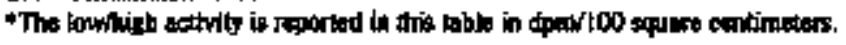


Table 2. Rediologkal survey resails an slab

\begin{tabular}{|c|c|c|c|c|c|c|c|}
\hline Dents & Survey \# & Locinion & $\underset{\operatorname{Sint} b}{\sin }$ & $\begin{array}{l}\text { Alpab snear } \\
\text { Frequency } \\
\text { lowitaigh }\end{array}$ & $\begin{array}{l}\text { Bete troekr } \\
\text { Frequency } \\
\text { lowbight }\end{array}$ & 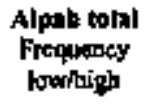 & $\begin{array}{l}\text { Bets iatt } \\
\text { Frequency } \\
\text { lowitiog }\end{array}$ \\
\hline 1280006 & $2006170 \$ 1 D U D E S K 002$ & $\begin{array}{l}\text { shb, sonth } \\
\text { end middite } \\
\text { sectian }\end{array}$ & $<5400.5$ & W/A & $N / A$ & $\begin{array}{l}11 / 700 \\
26 / 40\end{array}$ & $\begin{array}{c}7480 \\
3724000\end{array}$ \\
\hline $2 / 282007$ & 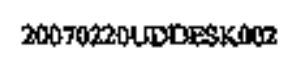 & $\begin{array}{l}\text { Silab, sounl } \\
\text { and }\end{array}$ & PCA & $\begin{array}{l}0 / 34 \\
<1\end{array}$ & $\begin{array}{l}0.34 \\
<L_{1}\end{array}$ & $N / A$ & NtA \\
\hline $2 / 272007$ & 2047022:HCS2DFSKDOI & $\begin{array}{l}\text { Slab, south } \\
\text { and }\end{array}$ & FCA & $\begin{array}{l}0,49 \\
\times 4\end{array}$ & $\begin{array}{l}0.49 \\
\times L_{4}\end{array}$ & $\mathbf{N} / \mathbf{A}$ & N/A \\
\hline $3 n 22007$ & $20070312405 D E S K 001$ & $\begin{array}{l}\text { Skb, south } \\
\text { and }\end{array}$ & $<5400.5$ & N/A & $\mathbf{N} / \mathbf{A}$ & $\begin{array}{l}0,50 \\
<1\end{array}$ & $\begin{array}{l}\text { arso } \\
<10\end{array}$ \\
\hline 10042007 & OT-ATEA.0953 & $\begin{array}{l}\text { Stab, } \\
\text { upnthwest } \\
\text { corac }\end{array}$ & $<5400.5$ & $\begin{array}{l}\text { WIO } \\
<L_{c}\end{array}$ & $\begin{array}{l}\text { WJo } \\
<k=\end{array}$ & $\begin{array}{l}0+55 \\
<L_{t}\end{array}$ & $\begin{array}{l}\text { OSIs } \\
<\mathrm{L}\end{array}$ \\
\hline $102 / 2007$ & OH-Nient-0954 & 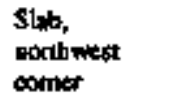 & $x$ sinoos & $\begin{array}{c}1+50 \\
21\end{array}$ & $\begin{array}{l}050 \\
<t\end{array}$ & $\begin{array}{l}0.50 \\
\times 54\end{array}$ & $\begin{array}{l}1 / 50 \\
517\end{array}$ \\
\hline $10 \mathrm{26} 2007$ & 07-Atreah-0965 & $\begin{array}{l}\text { Sleb, northest } \\
\text { comer }\end{array}$ & PCA & $\begin{array}{l}1150 \\
21\end{array}$ & $\begin{array}{l}1 / 50 \\
249\end{array}$ & $N A$ & $\mathbf{N} / \mathbf{A}$ \\
\hline 102912007 & Ot-At:셧-0957 & $\begin{array}{l}\text { Stab, ponthengt } \\
\text { tection }\end{array}$ & $\mathrm{FCA}$ & $\begin{array}{l}0440 \\
\times 1 .\end{array}$ & $\begin{array}{l}0,10 \\
\times L\end{array}$ & NHA & $w / A$ \\
\hline $10030 / 200 \%$ & 07.hreal-0959 & $\begin{array}{l}\text { slab, norlbet: } \\
\text { section }\end{array}$ & FCA & $\begin{array}{l}0 / 40 \\
\times \mathrm{L}\end{array}$ & $\begin{array}{l}0 / 40 \\
<L_{x}\end{array}$ & $N / A$ & MA \\
\hline $1031 / 2007$ & 07 -hreA-695 & $\begin{array}{l}\text { slab, portherat } \\
\text { esction }\end{array}$ & FCA & $\begin{array}{l}\text { OMAO } \\
<L \text { L. }\end{array}$ & $\begin{array}{l}\text { tor } \\
<10\end{array}$ & $M t / A$ & N/A \\
\hline 112004 & OT-AItah-0\%66 & 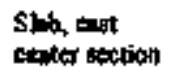 & $\mathrm{FCA}$ & $\begin{array}{l}0.106 \\
\times 10\end{array}$ & $\begin{array}{l}0.106 \\
<L_{5}\end{array}$ & $\mathrm{~N} / \mathrm{A}$ & N/A \\
\hline 1162000 & ot-Areudugns & $\begin{array}{l}\text { Slab, etst } \\
\text { cost:as sestion }\end{array}$ & FEA & $\begin{array}{l}0195 \\
<1 \text {. }\end{array}$ & $\begin{array}{l}0 / 15 \\
<L_{t}\end{array}$ & NA & N/A \\
\hline I $16200 \mathrm{nt}$ & D7-Arethog72 & 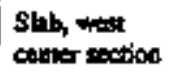 & $\mathbf{K C h}$ & $\begin{array}{l}1 / 20 \\
<L_{t}\end{array}$ & $\begin{array}{l}\text { O/20 } \\
<L_{2}\end{array}$ & NHA & $\mathbf{N} / \mathbf{A}$ \\
\hline
\end{tabular}

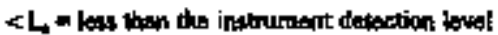

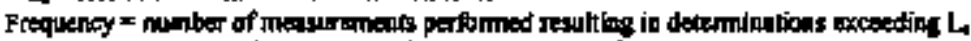

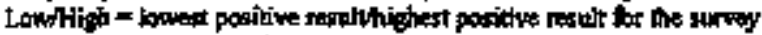

FCA $=$ fined contopialpation anr?

CA = continnination ares

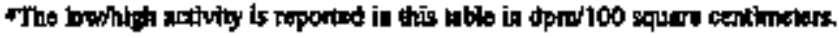




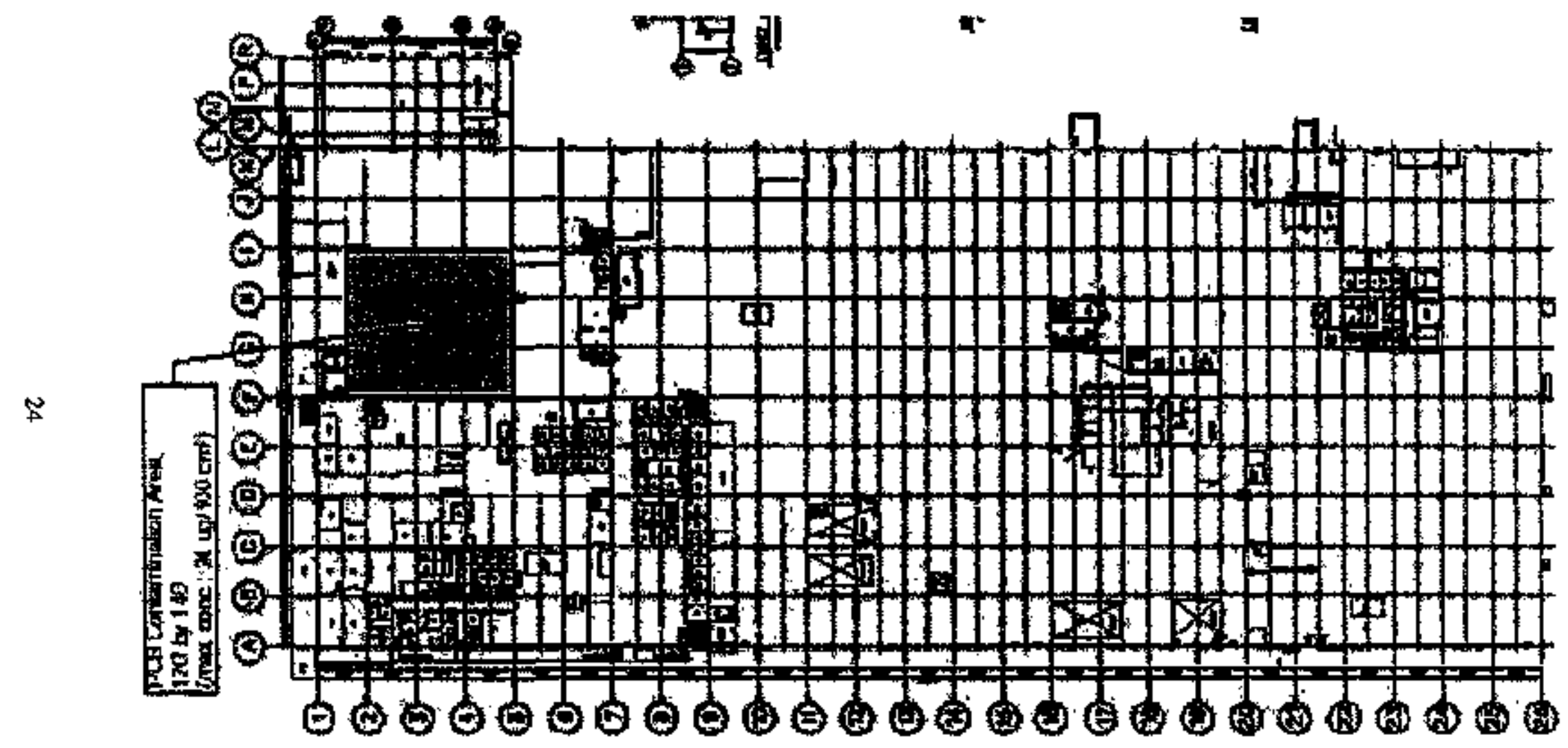

Fig. 11. Locetion of polychlorinated biphenyl contamination on the ginb. 


\subsection{DEVIATIONS FROM GOVERNING DOCUMENTS}

Deviafions from the Action Memorandum (DOE 2003a) are listed below:

- The demolition was not performed by a subcontractor but was self-perfomed by Bechtel lacobs Company LLC (BJC).

- The slab was not decontaminated, nor was a coating applied because plans are to excavate the slab by the end of Fiscal Year 2008.

Deviations from the Standard Operating Protocol (DOE 2003c) are listed below:

- The demolition tas pot performed by a subcontractor but was seti-performed by BJC.

- No evaluation of altetratives to reduce waste volumes was prepared because that isswe was addressed at a program level. Other than implenenting best management practices, volune reduction is not addressed in project level documents.

Deviations firm the Waste Handling Plan, Part 1 (DOE 20030) are listed below:

- The demolition was not performed by a subcontractor but was self-performed by BJC.

- No evaluation of alternatives to reduce waste volumes was prepared because that issue was addressed at a progran level. Other than implementing best management practices, volume reduction is not addressed in project level documents.

Deviatiens from the Waste Handling Plan, Part 2 (DOE 2005b) are listed below:

- A portion of the vent pipe was disposed at the EMWMF rather than off-site. 
Page Intentlaunlly Left Blants 


\section{WASTE MANAGEMENT AND TRANSPORTATION ACTIVITIES}

Waste management activities consisted of waste material being segregated, characterized, packaged, marked, and labeled is accordance with the WHP (DOE 2005b, DOE 2005e). The waste types, volumes, and disposal facilitites are presented in Table 3.

Tabjo 3. Waste disposel

\begin{tabular}{|c|c|c|}
\hline Waste Type & Volume (mbic feet) & Dispossl Outtot \\
\hline Enilding demolation debris & 842,341 & EMWMF-WL, 14.14 \\
\hline Building detmolition debris-vert pipe & 7 & EMWMF.WL 14.18 \\
\hline Bailding demolftion debris-vent pipe & 7 & Energysolutions \\
\hline Building derreolition debris & 2079 & EnergySalutions \\
\hline Butlding denolition debris & 810 & Off-site recyeler \\
\hline Butlding demolftion debris & 702 & Y-12 Landfill \\
\hline Universal waste & 897 & Off-site vendor \\
\hline $\begin{array}{l}\text { Liquid waste purinfed from basenent } \\
\text { (8/24/06-10/2/06) }\end{array}$ & 73,845 (552,364 gal.) & CNF \\
\hline $\begin{array}{l}\text { Liquid woste parnped from basement } \\
\text { (10/2/06-7/30/07) }\end{array}$ & $736,5: 7(5,509,146 \mathrm{gal})$. & Senitary sewer \\
\hline Oit & Is (115 gal.) & TSCA lncinerator \\
\hline Hazardous waste & 702 & Off-sits vendor \\
\hline
\end{tabular}

Total

$1,657,922$

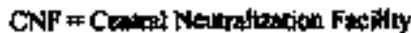

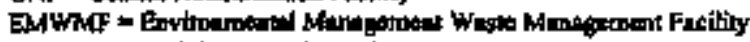

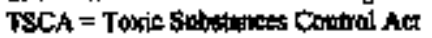

$W L=$ Watte Lox

The two EMWMF waste lots are described below:

- Waste Lot 14.14: EMWMF Waste Lot 14.14 inciudes the structure, contents, end equipment from Bldg. K-1401,

- Waste Lot 14.18: EMWMF Waste Lot 14.18 inchudes the vent pipe.

The universal waste consisted of light bulbs and batteries. Dernolition debris that was recycled was lend sheets from the X-ray roorn. Personal protective equipment wes disposed with the building cebris.

Liquid waste was pumped frora the basement to support demolition. Initially, it was treated at the Central Neutraljzation Facility and then at an on-site pre-treatment facility and discharged to the satitary sewer. 
Prge Intentionally Left Błank 


\section{COST AND SCHEDULE}

Demtolition of Bldg. K.140] was completed for a cost of $\$ 26,820,000$ as detailed in Table 4.

Table 4, Cost (\$X1000)

\begin{tabular}{ll}
\hline Characterization & 603 \\
Deactivation & 90 \\
Derrodition & 24,685 \\
Project maragement & 1442 \\
Total & 26,820 \\
\hline
\end{tabular}

Since this action represents only a portion of the scope in the Action Memorardum (DOE 2003a), a comparison of the total costs will be provided in the Removal Action Repert.

A summary schedule for this action is shown below:

- Start Removal Action-August 23, 2004

- Start Building Demojition (stnuctural)-August 24, 2006

- Complete Demolítion-September 28, 2007

- Complete Waste Disposal-Fobruary 28,2008 


\section{Page Iotenfionally Left Blank}




\section{OPERATION AND MAINTENANCE PLANS}

No long-tem operation and matntenance requirements are associated with this action. 
Page Iotentlonally Left Bdank 


\section{MONITORING}

Monitoring of the Bldg. K-1401 slab will be performed on an interim besis until a final remediation decision is made as part of the Zone 2 ROD (DOE 2005a). A summary of the monitoring is in Table 5. Following is a more detailed explanation of the interim monitoring to be pertormed.

Table S. Monitoritug summary

\begin{tabular}{|c|c|c|c|}
\hline Cocation & Typt: & Parameters & Frequency \\
\hline Storm drains 180 end J90 & Environmental & $\begin{array}{l}\text { Gross alpha, gooss beta, } \\
\text { uramilm isotopic, } \\
\text { techmotiuno-99 }\end{array}$ & 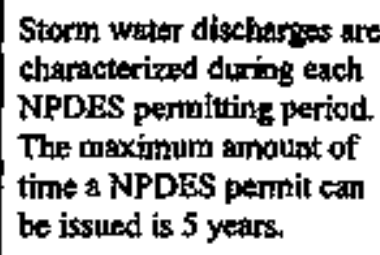 \\
\hline $\begin{array}{l}\text { Mitchel] Branch at the } \\
\text { K-1 } 700 \text { Weir }\end{array}$ & Environnental & $\begin{array}{l}\text { Gross abpha, gross beta, } \\
\text { uranilum isctopic, } \\
\text { techrettam-99 }\end{array}$ & Arnual \\
\hline K-140I Pad & Radiological & Removable & Armual \\
\hline
\end{tabular}

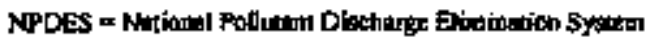

Environmental monitoring will be perfonned in accordance with 10 Code of Federal Regulations (CFR) 835, DOE Orders 450.1 (DOE 2003b) and 5400.5 (DOE 1993), and the National Poltutant Discharge Elinination System storm water permit until nemediation is compiette, in general, storm water runoff from concrete pads is not sampled. Instead the radiation contamination control and surveitlance progran is used to meet the DOE Order 5400.5 requirenentr because outdoor radiological contamination is controlled through the radiation control posting and radiological control effort When a slab, field, or bujlding is posted for radiological controls, then the area becomes part of the radiologital surveillance and monitoring program. If ratiological contamingtion is found to be migrating out of the contarnination aren, then additional controls are implemented to control the contamination. The frequency and level of strveillance and montioring is establlshed at each site by the radiation engineers responsible for the program. The Environmental Compliance Program determines the effectiveness of the radiation control program through the ongoing stonm drain outfill sampling and the instream water sampling in Mischell Branch, K-I007-P! Pond, and K.901-A Pond. This sampting is compared to screening levels established at $4 \%$ of DOE Onder 5400.5 derived concentration guideline levels to maintain distharyes as low as reasonably achievable. When the screening levels are exceded, a fiek irvestigetion is conducted to determine the source of radjological release, Corrective measures, such as upgrasied stom water erosion controls, are implemented as needed. Specifically, radiological monitoring of the perimeter wist be performed, and radiation controls will be maintained as long as the meed exists. There is a continuous evaluation of the control program during denolition and rezrefiation, and following renedistion an appropriate program will be developed.

The storm water mutof from the Bldg. K-1401 pad is drained by storm drains I80 and 190 into the Mitchell Branch. The surface water from Mitchell Brasch witl be monitered on at least an arrual bagis for at a minimum the following parameters: gross alpha, gross beta, uraniurn isotopic, and "Technetion. The storm water discharges fron storn trains 180 and 190 are characterized folly during each National Pallutant Discharge Elimination System permitting period in accordance with starm water pollution 
prevention plans. The permits ean be issued for a period as long as five years although the current ETTP storm water permit was issued for a four year period so that the expiration date will be consistent with the State of Tennessee watershed schectule for this area of the state. The stom drains 180 and 190 characterization monitoring will at a minimum include the following parameters: gross alpha, gross betz, uranisum isotopic, and ${ }^{59}$ Technetilim.

BJC and its stbcontractors perform radjological work at ETTP. DOE section of the CFR that governs radiological operations at DOE facilities is 10 CFR 835, Occupational Radiation Protetion. 10 CFR 835, Subpart B, section (a) states "A DOE activity shall be conducted in compliance with a documented radiation protection prograr as approved by DOE." BJC operates usder a DOE approved radiation protection program, portions of which are ticorporated into "Radiation Protention Program Description for BechteI-Jacobs Company LLC Oak Ridge, Tennessee" (BJC 2007).

The 10 CFR 835 requirtments that relate to monitoring of areas are found in Subpart E, Section 401(a) that states: (a) Monitoring of individuals and areas shall be performed to:

- Demonstrate compliance with the regulations in this part

- Document tadiological conditions

- Detect changes in tadiological conditions

- Detect the gradual buildup of radiosetive material

- Verify the effectiveness of engineering and process controls in containing radionctive material and reducing radiation exposure

- Identify and control potential sources of individual exposure to radiation and or tadioactive material

The requirements relative to Fixed Contamination Areas are found in Subpart $\mathrm{L}$, Section 1102(c) that states: (c) Areas accessibje to individuals where the measured total surface contantination levels exceed, but the removable surface contamization levels are less than, corresponding surface contamination values speciffed in appendix D of (10 CFR 835), shall be controlled as follows when located outside of rexiological areas: (1) The area shall be routinely monitored to ensure the removable surface contanaination level nernains below the removable sturface contamination values specified in appendix D to 10 CFR 835; and (2) The area shall be conspictocusly merked to warn individuals of the contaminated statis. The values specified in 10 CFR 835, Appendix D and the BJC administrative release values are presented in Table 6. 
Table 6. Surface contamination values in dpm/100em²

\begin{tabular}{|c|c|c|c|c|}
\hline \multirow{3}{*}{ Radionuclide } & \multicolumn{4}{|c|}{ Surface contanknation values' fo dpm/10 $\mathrm{co}^{22}$} \\
\hline & \multicolumn{2}{|c|}{ Removable 24} & \multicolumn{2}{|c|}{$\begin{array}{l}\text { Total (Tyred + } \\
\text { removable) }\end{array}$} \\
\hline & 10 CFR 835 & BJC Admin & 10 CFR 835 & BKC Admìn \\
\hline U-uat, U-235, U-238, and associated decay products & $1000^{7}$ & 800 & $5000^{2}$ & 4000 \\
\hline $\begin{array}{l}\text { Transuranics, Ra-226, Ra-228, Th-230, Th-228, Pa- } \\
\text { 231, Ac-227, I-125, 1-129, }\end{array}$ & 20 & 20 & 500 & $\$ 00$ \\
\hline $\begin{array}{l}\text { Th-nat, Th-232, S-90, Ra-223, R-224, U-232, J- } \\
226, \mathrm{I}=131, \mathrm{I}-133\end{array}$ & 200 & 160 & 1000 & 800 \\
\hline $\begin{array}{l}\text { Beta-Ganma emitters (nueltdes with decay modes } \\
\text { other then alpha emission or sponteneens fission) } \\
\text { oxcept } \mathrm{Sr}-90 \text { and others noted in }{ }^{3}\end{array}$ & 1000 & 800 & 5000 & 4000 \\
\hline Tritium and Tritiated confnpounds" & 10,000 & 8000 & $\mathbf{N} / \mathbf{A}$ & $N / A$ \\
\hline
\end{tabular}

'The vakes in this appendix, with the exception noted in foobnote 5, apply to radiogctive contaningtion deposited on, but not

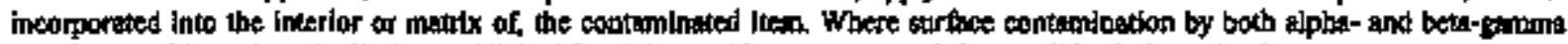

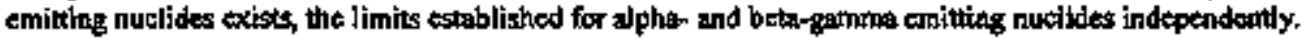

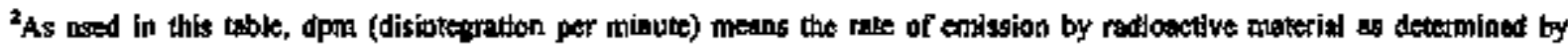
contecting the counts per minute observed by an appropriate detector for background efficiency, and geometric factors associaled with the instrumentorion.

${ }^{3}$ The lewels mry be averaged ower one square moter provixid the maximum sarface activity in any area of $100 \mathrm{~cm}^{2}$ is itss that threc times the vahue specified. For puiposes of fveraging any squane meter of surface shill be constidered to above the surfar

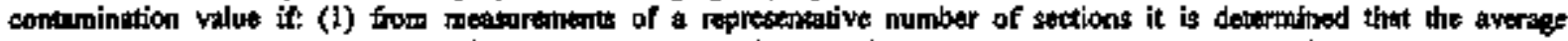
contumination level exceeds the applicable value; or (2) it is deternined that the sum of the activity of all jsolated spots or particles in any $190 \mathrm{~cm}^{3}$ wea excecds three timed the applictole value.

The annount of removabie radioective malerial por $190 \mathrm{~cm}^{2}$ of surflce erea shoklld be detcropined by swiping the area with dry

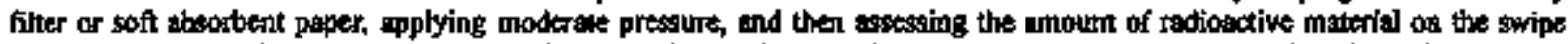

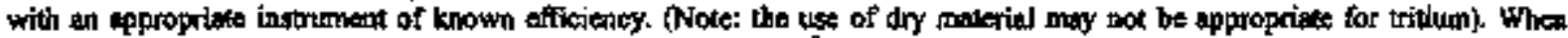
Iemovible contaninetion objects of surface area less than $100 \mathrm{~cm}^{2}$ is detemined, the activity per unit aroa shall be based os the

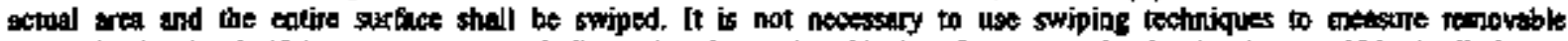

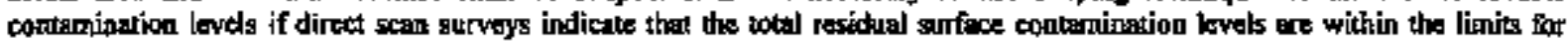
recrovable contamianation.

'This calcony of radionuclises includes mixed fission produets, including the Sr-90 which is present in them lt does not apply

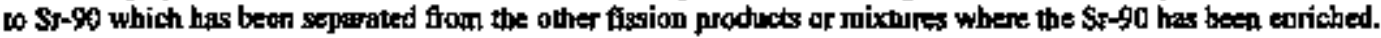

${ }^{5}$ Trillum contarnination may diffuse into the vohume or matrix of anterials. Evalontions of surfice ocatamination shall consider

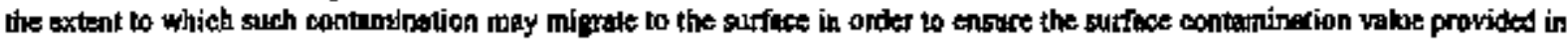
this appendix is not exceeded. Onca this contanination miggates to the surface, it dray be remowahle, not fixed, therefore, a Toters yaltio does nol apply

'Alpha 
BJC procedurgl requirements relative to monitoring of areas are found in Section B, "Workplace Monitoring" that states: (1) Assure that radiation and contamination surveys are perfonmed on a frequency necessary to document radiological conditions in the workplact, detect changes in radjological conditions, and verify the effectiveness of physical design features in reducing exposares, and (2) Perforn routine and task specific radiation and contamination surveys on a frequency:

- As specified by the routine radiological survey schedule, Radiological Work Pentits, RADCON Procedures, and as directed by supervision

- Daily for contamination at active Boundary Comtrol Stations

- Routinely in offices and break/lanch rooms that have the potential for contamination

- Before, duriag and after work (if appropriate) that has the potential for causing changes in radiation exposure or contamination conditions

The Workplace Monttoring Topical Guide (BJC 2006) provides guidance on contamination monitoring frequencies and states: Contamination moritoring programs should be revieured annually by the Project Health Physiclist to ensure that appropriate surveys are performed at a frequency that is consistent with existing and potential hazards and activities planned in the area. The following survey fiequencies are suggested and should bo modified in a documented annual monitoring progrem review, as necessary, to ensure that area hazards are adequately characterized based upon facility-specific experience:

- Prior to transfer of equipment and material from one Radiological Buffer Area, that is established for contarimation control to another, unless the material was monitored immediately prior to this transfer, such as upon removal from a Contamination Atea

- Prior to transfor of equipnent and material from High Contamination Areas within Radiological Buffer Areas unless precautions such as bagging or wrapping are taken prior to transfer

- Daily, at Contamination Area control points, change areas, or step-off pads when in use, or in accordance with a shift in high use situations

- Daily, in office space located in the Radiological Buffer Areas

- Dajly, in lunch rooms or eating areas near the Radiological Buffer Areas

- Daily in accessible areas where cperations aro under way that are likely to produce hot particies

- Weekly, in rourtinely occtrpied Radiological Buffer Areas

- Weekily, or upon entry, if eutries are less freçuent in Contanination Areas and other areas where materials having removabie contamination exceeding surface value guidelines are handied or stored

- Weekly, or upon entry, if entries are less frequent, where Contamiration Area boundaries or postings are located

- During initial entry into a known or suspected Contamination Ares, periodically during work, at the completion of a job, or as specified in an Radiation Work Permit

- At least annually, in and around areas of fixed contanination

- After a leak or spill of radioactive materials 


\section{LAND-USE CONTROLS}

Interim land-use controls are required following completion of this action to control aceess to the portion of the rernaining concrete slab that has restival polychlorinated biphenyl contamination and is posted as a radiological Contamination Area. The interin controls will remain in place until the Remedial Action Project determines if additional remediation of the slab is necessary. The Zone 1 (DOE 2002), Zone 2 (DOE 2005a), and furture Sitewide Records of Decision will establish final land-use controls following remediation of ETTP. 
Page Intentionally Leff Blonk 


\section{REFERENCES}

BJC (Bechtel Jacobs Company LLC) 2004, Limited Čharacterization Plan for the Main Plan Phase I Facilities, East Tennessee Technology Park, Oak Ridge. Tennessee, BJC/OR-1720, Bechtel Jacobs Company LLC, Oak Ridge, TN.

BUC 2006. Workplace Monitoring Topical Guide. RAD-4500-9.

BJC 2007. Radtation Protection Program Description for Bechtel Jacobs Company, LLC, Oak Ridge, Tennetsee. BJC-EH-4000. Bechtel Jacobs Company LLC, Oak Ridge, TN.

DOE (U.S. Department of Energy) 1993. Radiation Protection of the Public and the Environment, DOE Order 5400.5, Chg.2, U.S. Department of Energy, Washington, D.C.

DOE 1997. Action Memorandum for Reronting of Sump Discharge from Buildings $K-J 401$ and K-1420, East Tennessee Technology Pork, Oak Ridge, Tennessee, DOE/OR/02-1610\&D1, U.S. Department of Energy, Office of Environmental Management, Oak Ridge, TN.

DOE 1998. Removal Action Repart on the $K-1401 / K-1420$ Sumps Removal Action at the Bast Tennesset Technology Park, Dak Ridgt, Tennessee, DOE/OR/O1-1754\&D2, U.S. Department of Energy, Otfice of Exvironmental Matlagement, Oak Ridge, TN..

DOE 2000. Bngineering Evaluation/Cast Anolysis for the K-25 Amxiliary Facfities Demolition Project Growp II Butldings at the East Tennessee Technology Park, Oak Ridge, Tennessee, DOE/OR/01. 1765\&D4, U.S. Departrent of Energy, Office of Environmental Management, Oak Ridge, TN.

DOE 2002. Record of Decision for Interim Actions in Zone I, East Tennessee Technolozy Park, Oak Ricige, Tennessee, DOEJOR/01-i997\&D2, Environmental Marsgenent Program, Oak Ridge, TN.

DOE 2003a, Action Memorandum for the Remaining Facilities Demolition Project at East Tennessee Technology Park, Oak RIdge, Tennessee, DOEOR/01-2049\&D2, U.S. Department of Energy, Office of Environmental Management, Oak Ridge, TN.

DOE 2003b. Envtronmental Protection Program, DOE Order 450.1, Admin Chg. 1, U.S. Department of Energy, Washington, D.C.

DOE 2003c. Standard Operating Protocol for the Remaining Facilities Demalition Project, East Tennessee Techology Park, Oak Ridge, Tennessee, DOE/ORNO1-2 I CO\&D1, U.S. Department of Energy, Office of EnvironmentaI Managernent, Okik Ridge, TN.

DOE 2003d. Waste Handling Plon, Part I, for the Remaining Facilities Demolition Project, East Tennessee Technology Park, Oakk Ridge, Tennessee, DOE/OR/01-2089\&D1, U.S. Departuent of Energy, Office of Environmental Management, Osk Rudge, TN.

DOE 2005a, Recard of Decision for Sofl, Buried Waste, and Subsuface Structure Actions in Zone 2, East Temessee Technology Park, Oak Ridge, Tennessee, DOE/OR/01-2161\&D2, Envirommental Managenent Program, Oak Ridge, TN. 
DOE 2005b. Waste Handling Plan-Part 2 for Bldg. K-1401 of the Remaining Factlities Demolition Project at the East Termessee Technology Park, Oak Ridge, Tennessee, DOE/OR/012209\&D1/DEL, Environmental Management Program, Oak Ridge, TN.

DOE 2005c. Waste Handling Plan-Pant 2 for Bldg. K-140I of the Remaining Facilities Demolition Project at the East Tennessee Technology Pank Oak Ridge. Tennessee, DOE/OR/Ol-2209\&D1 \&RI/DEL, Enviromental Management Progrem, Oak Ridge, TN.

DOE 2006. Addendum for Remowal Action Report on the K-1401/K+1420 Sumps Removal Action at the East Tennessee Technology Park Oak Rudge, Tennessee, DOE/OR/01-1754-D2/Al, U.\$. Department of Energy, Office of Environuental Managenent, Oak Ridge, TN.

DOE 2007. Letter from Devid Adler and Donna Perez, DOE, dated March 26, 2007, SUBJECT: Notification of Non-Significant Change to the Action Memorandum for Rerouting of Sump Discharge from Buildings $K-1401$ and $K-1420$, East Tennessee Technology Park Oak Ridge, Tennessee (DOE/OR/02-L6108D1) to Joffrey Crane, Environmental Protection Agency and Doug McCoy, Tennessee Deparment of Environment and Conservation. 
DOE/OR/01-2365\&D2

\section{RECORD COPY DISTRIBUTION}

File-DMC-RC 
DOCUMENT TITLE: Phaged Construction Completton Report for Bldg. K-1401 of the Remaining Facliltles Demoltifon Project at the East Tennesseo Technolody Park, Oak Rlikge, Tennessoo

DOCUMENT NUMBER: DOERORS1-2365\&D1

NANE OF REVIEWER: Angel Perkey. TDEC

DATE CORUENTS RECEIVEO; April 30, 2008

\begin{tabular}{|c|c|c|c|}
\hline No. & $\begin{array}{l}\text { SECT } \\
\text { PAGE }\end{array}$ & COAMENT & RESPONSE \\
\hline 1. & General & $\begin{array}{l}\text { An Addendum to the Waste Handing Plan-Part } 2 \text { is } \\
\text { required for the secton of vent plpe that was inadvertently } \\
\text { disposed of at the ERMWh. The Addendum should be } \\
\text { submitted to and approved by the State and EPA before } \\
\text { thig PCCR could be aporoved. }\end{array}$ & $\begin{array}{l}\text { An Addendum to the Waste Handling Plan - Part } 2 \text { has } \\
\text { begn prapared for the vent pipe and submitted to the } \\
\text { EPA and TDEC for approval. }\end{array}$ \\
\hline 2. & $\begin{array}{l}\text { Section 2.3, } \\
\text { Facility } \\
\text { Description }\end{array}$ & $\begin{array}{l}\text { In the description of the areas of the building, please } \\
\text { identify the areas that were leased to the Comminuly Reuse } \\
\text { Organization of East Termessee. Provtde more mformation } \\
\text { regarding the decontanination efforts that supported the } \\
\text { eeasing. }\end{array}$ & $\begin{array}{l}\text { Sectlon } 2.3 \text { has been revised to ldentify the areas that } \\
\text { were leased to the Community Reuse Organization of } \\
\text { East Tenressee. }\end{array}$ \\
\hline 3. & $\begin{array}{l}\text { Section 2.3. } \\
\text { Fecility } \\
\text { Description }\end{array}$ & $\begin{array}{l}\text { In the sectlon that describes the basement, include mare } \\
\text { informatton about the prevlous CERCLA removel action for } \\
\text { the sumps. Include discussion about the subsequent } \\
\text { agreament to discontinus use of the sumps. }\end{array}$ & $\begin{array}{l}\text { Section } 2.3 \text { has been revised to incorporate information } \\
\text { on tha CERCLA removal action for the sumps. }\end{array}$ \\
\hline 4. & $\begin{array}{l}\text { Section 3, } \\
\text { Project } \\
\text { Description, } \\
3^{\text {rd }} \\
\text { peragraph, } \\
5^{\text {th bullet }}\end{array}$ & 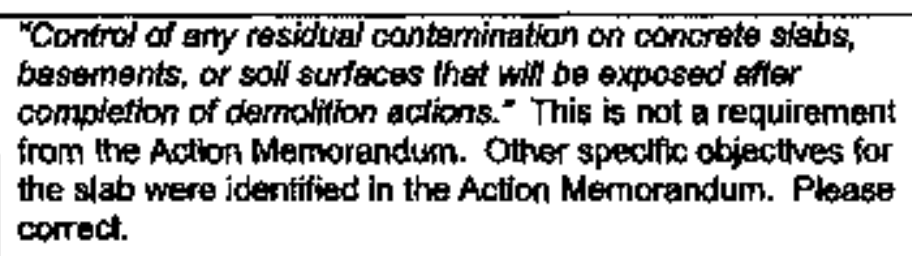 & $\begin{array}{l}\text { Section } 3 \text { has been revised to include the scope from } \\
\text { Section } 5 \text { of the Action Memorandum. }\end{array}$ \\
\hline 5. & $\begin{array}{l}\text { Section 4.1, } \\
\text { Demoltion } \\
\text { Activitles, } 5^{\text {th }} \\
\text { bullet, } \mathbf{1}^{*} \\
\text { dasta }\end{array}$ & 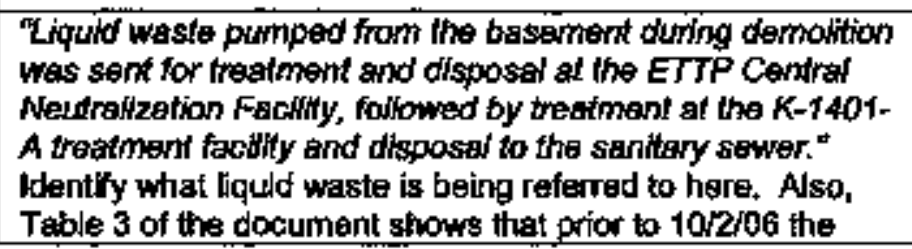 & $\begin{array}{l}\text { Section } 4.1 \text { hes been revised to indicate that the liquid } \\
\text { waste is groundwater and to explaln why the treatment } \\
\text { fackity changed. }\end{array}$ \\
\hline
\end{tabular}




\begin{tabular}{|c|c|c|c|}
\hline NO. & $\begin{array}{l}\text { SECT/ } \\
\text { PAGE }\end{array}$ & COMMENT & RESPONSE \\
\hline & & $\begin{array}{l}\text { liquid waste was pumped to CNF and after that date if was } \\
\text { pumpad to the sanitary sewer. Explain why this change } \\
\text { cocurred. }\end{array}$ & \\
\hline 6. & $\begin{array}{l}\text { Section } 4.1 . \\
\text { Demolition } \\
\text { Activatios, } 9^{\text {th }} \\
\text { bullet }\end{array}$ & 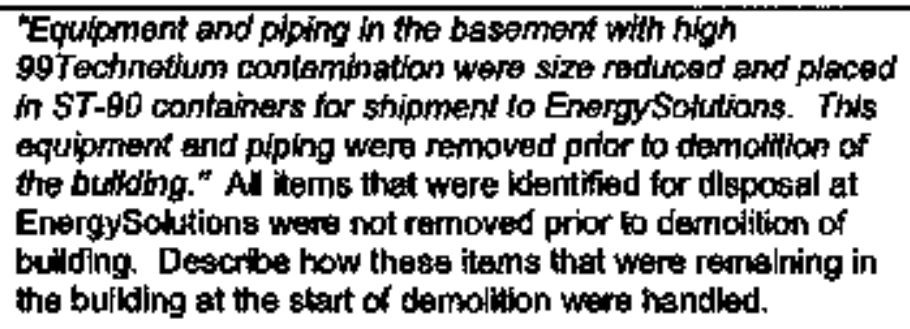 & $\begin{array}{l}\text { Secllon } 4.1 \text { has been revised to describe how the items } \\
\text { remaining in the building at the start of demolition were } \\
\text { handled. }\end{array}$ \\
\hline 7. & $\begin{array}{l}\text { Section } 4.2, \\
\text { Attainment } \\
\text { of Objectres }\end{array}$ & $\begin{array}{l}\text { Inciude dlscussion about how the water that accumulated in } \\
\text { the plits, treniches, and basement area during demolition } \\
\text { was managed. }\end{array}$ & 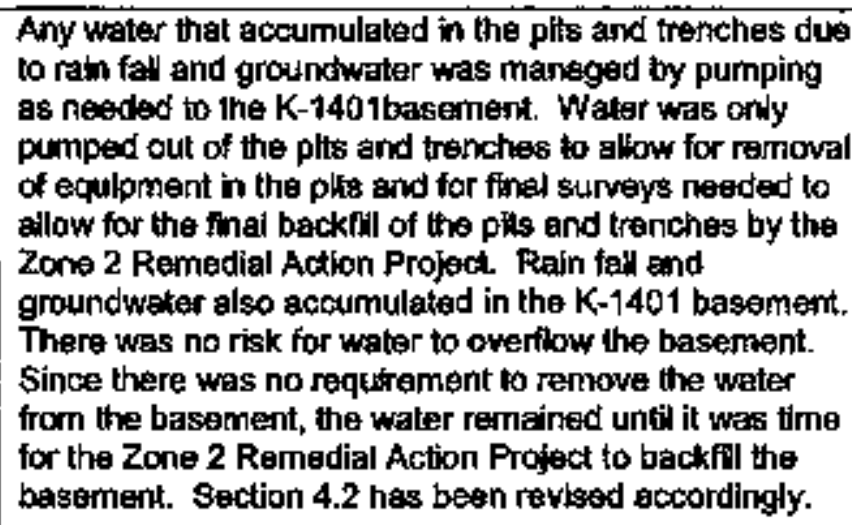 \\
\hline 8. & $\begin{array}{l}\text { Section 4.3, } \\
\text { Unexpected } \\
\text { Occurrence }\end{array}$ & $\begin{array}{l}\text { Provide a better explanation for how the vent pipe was } \\
\text { inadvertently disposed of at the EhWWMF. Spectlosily, } \\
\text { dlscuss that the phee was to be palnted to Identlfy it for } \\
\text { disposal at Energysolutions. Explain why the painting } \\
\text { newer occurred. }\end{array}$ & Section 4.3 has been revised accordingly. \\
\hline$\ddot{9}$ & $\begin{array}{l}\text { Section 4.3, } \\
\text { Unexpected } \\
\text { Occtirrence, } \\
3^{\text {N }} \\
\text { Peragraph }\end{array}$ & $\begin{array}{l}\text { The remaining } 33 \text { f. of pipe were disposed at the } \\
\text { EMWMF." Rephrase this senlence to say that following the } \\
\text { investigation, DOE made the determination that the pipe } \\
\text { was disposed at the EMWMF. }\end{array}$ & Section 4.3 has been revised accordingly. \\
\hline
\end{tabular}




\begin{tabular}{|c|c|c|c|}
\hline No. & $\begin{array}{l}\text { SECTI } \\
\text { PAGE }\end{array}$ & COMMENT & RESPONSE \\
\hline 10. & $\begin{array}{l}\text { Section 4.4. } \\
\text { End Staig }\end{array}$ & $\begin{array}{l}\text { Inchide a figure that shows the locations and sizes of the } \\
\text { pits and trenches. }\end{array}$ & A rigure has been included. \\
\hline 11. & $\begin{array}{l}\text { Section 4.4, } \\
\text { End State, } \\
\text { Figure } 9\end{array}$ & $\begin{array}{l}\text { It is not possible to distingulish between the shading for the } \\
\text { Fixed Contamination Area and the Clean Area. Prowide e } \\
\text { different figure. }\end{array}$ & $\begin{array}{l}\text { Blue is used for the Fixed Contemination Area, and } \\
\text { green is used for the Clean Area. These two colors cen } \\
\text { be distinguished in the document, so no change has } \\
\text { been made to the figure. }\end{array}$ \\
\hline 12. & $\begin{array}{l}\text { Section } 4, \overline{4} \\
\text { End State, } \\
\text { Table } 1\end{array}$ & $\begin{array}{l}\text { Tn Section } 4.4 \text { of the document, describe how these } \\
\text { rediological survoys were accomplished, considering that } \\
\text { the basement generalfy has several feet of water standing } \\
\text { in it. Also, include discussion abourt which constituents are } \\
\text { contibulting to the high total bele values. }\end{array}$ & 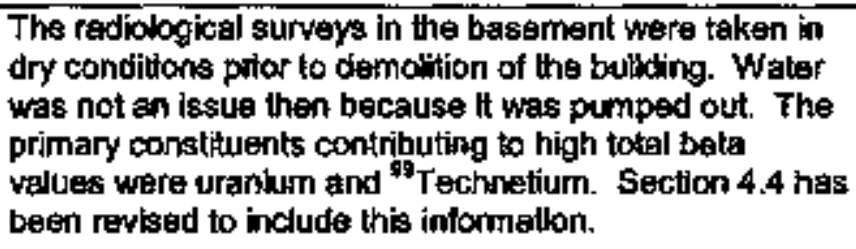 \\
\hline 13. & $\begin{array}{l}\text { Section } 4.4 . \\
\text { End State. } \\
\text { Figure } 10\end{array}$ & $\begin{array}{l}\text { In Section } 4.4 \text { of the document, hockude the range of PCB } \\
\text { contamination remaining in the basement. Also, there } \\
\text { appears to be some confusion over whether a fixetive was } \\
\text { actually applied to the contaminated locition. Please } \\
\text { confirm whether this occurred or not. }\end{array}$ & $\begin{array}{l}\text { Bectlon } 4.4 \text { has been revised to Inctude the renge of } \\
\text { PCB contemination remaining in the basement. Fixative } \\
\text { was not applied to the shat contaminated with PCBs } \\
\text { because the slab was remowed. Section } 4.4 \text { hes been } \\
\text { revised accordingly. }\end{array}$ \\
\hline 14. & $\begin{array}{l}\text { Section } 4.5 \\
\text { Deviations } \\
\text { from } \\
\text { Governing } \\
\text { Documents }\end{array}$ & $\begin{array}{l}\text { This does not appear to be a comprehensive ilst of all } \\
\text { deviallons, particularly thase related to end stale of the } \\
\text { slab. }\end{array}$ & $\begin{array}{l}\text { Section } 4.5 \text { has been revised to include deviations for } \\
\text { the slab end state. }\end{array}$ \\
\hline 15. & $\begin{array}{l}\text { Sertion } 5, \\
\text { Waste } \\
\text { Management } \\
\text { and } \\
\text { Transportati } \\
\text { on Activities. } \\
\text { Table } 3\end{array}$ & $\begin{array}{l}\text { Section } 5 \text { should include disctrsion on the various types of } \\
\text { waste that were disposed, partioularly the two different } \\
\text { waste types disposed at EnergySolutions and the material } \\
\text { sent to the off-site recyder. }\end{array}$ & $\begin{array}{l}\text { The only resson two waste types are shown for disposal } \\
\text { at Energysolutions to to highlight the vent phpe. } \\
\text { Normally, the demoliton debrls disposed at } \\
\text { Energysolutions would have been combined. The third } \\
\text { paragraph in Secton } 5 \text { says lead was recycled. Section } \\
5 \text { has not been revised. }\end{array}$ \\
\hline 16. & $\begin{array}{l}\text { Section } \dot{8}, \\
\text { Monitoring }\end{array}$ & $\begin{array}{l}\text { The State requires additional information about the high } \\
\text { leveis of contamination remainixg on the slab and } \\
\text { basement area before we can determine if the monitoring } \\
\text { described in Section } 8 \text { is edequate. }\end{array}$ & $\begin{array}{l}\text { Since the slab has been rerncoved, no changes have } \\
\text { been made to Section } 8 \text {. }\end{array}$ \\
\hline
\end{tabular}

K-1401 PCCR D1 cOTII TDEC 043009 response. doc

Page 3 of 3 